\title{
The Impact of Nonlinear Fiscal Decentralization, Green Energy, and Policy Uncertainty on Sustainable Environment? A New Perspective From Ecological Footprint in Five OECD Countries
}

Samia Zahra ( $\sim$ samiazahra022@gmail.com )

Government of Khyber Pakhtunkhwa Department of Higher Education Archives and Libraries https://orcid.org/0000-0002-8832-053X

Ramez Abubakr Badeeb

Curtin University Malaysia Campus

\section{Research Article}

Keywords: Fiscal Decentralization, Green Energy, Economic Policy Uncertainty, OECD, Environmental sustainability, Asymmetric

Posted Date: January 18th, 2022

DOI: https://doi.org/10.21203/rs.3.rs-1205306/v1

License: (c) (1) This work is licensed under a Creative Commons Attribution 4.0 International License.

Read Full License 


\title{
The Impact of Nonlinear Fiscal Decentralization, Green Energy, and Policy Uncertainty on Sustainable Environment? A New Perspective From Ecological Footprint in Five OECD Countries
}

\author{
Samia Zahra ${ }^{1 *}$, Ramez Abubakr Badeeb ${ }^{2}$ \\ ${ }^{1}$ Higher Education Archives and Libraries Department, Khyber Pakhtunkhwa, Pakistan \\ Email: $\underline{\text { samiazahra022@gmail.com }}$ \\ ${ }^{2}$ Faculty of Business, Curtin University Malaysia, Malaysia. \\ Email: ramez.abubakr@curtin.edu.my \\ Postal address: ISSB Road, Near Karwan Model College, New Galla Khel, Kohat.
}

Corresponding Author*: Samia Zahra

Email: samiazahra022@gmail.com

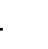

\section{Abstract}

The paper explores the short-run and long-run asymmetric impact of fiscal decentralization, green energy, and economic policy uncertainty on environmental sustainability proxied by ecological footprint. Using the Nonlinear Autoregressive Distributed lag (NARDL) approach in selected five OECD countries, we find that ecological footprint responds to positive and negative fiscal decentralization asymmetrically in the long run and short run. However, the nature of the response varies significantly across countries. The result also suggests that green energy is a major factor in reducing the ecological footprint in all countries except Canada. Finally, economic policy uncertainty plays a negative and significant role in the ecological footprint in the UK, US, and Germany while insignificant in Australia and Canada. Implications for effective environmental policies are discussed.

Keywords: Fiscal Decentralization, Green Energy, Economic Policy Uncertainty, OECD, Environmental sustainability, Asymmetric. 


\section{Introduction}

Since the World Earth Summit in Kyoto, Japan 1997, creating a sustainable environment has become a significant world issue in the global context. The summit initiated the need to protect our planet from the global environmental crisis. Approximately $80 \%$ of the world's population lives in a country plagued by major ecological issues. Human living standards and well-being have risen dramatically in recent decades because of significant economic expansion and prosperity (Majeed et al., 2021). This puts strain on the ecosystem, resulting in emissions, biodiversity loss, and environmental imbalance (Ahmed \& Wang, 2019; D. Lin et al., 2015; D. Lin et al., 2018; Vetter et al., 2014). Therefore, formulating and achieving sustainable environmental objectives becomes a top priority agenda to be addressed globally.

Scholars recently have introduced several factors that can contribute to a sustainable environment; which include fiscal decentralization (H. Chen et al., 2018; Hao et al., 2020; Ji et al., 2021; Shi et al., 2018), green energy (Adams et al., 2020; Charfeddine \& Kahia, 2019; de Souza et al., 2018; Majeed \& Luni, 2019; Öztürk et al., 2020; Rasoulinezhad \& Saboori, 2018; Riti \& Shu, 2016), and reducing economic policy uncertainty (Adedoyin \& Zakari, 2020; Anser et al., 2021; Pirgaip \& Dinçergök, 2020; Ulucak \& Khan, 2020; Q. Wang et al., 2020; Yu et al., 2021) as an important factor to preserve our planet and thereby creating a sustainable environment.

Fiscal decentralization has occupied a central place in international economic patterns (L. Wang \& Lei, 2016). It is a process of decentralization or power delegation to local political authorities to consider controlling important political and economic decisions in the best interest of economic objectives (Hao et al., 2020). There are two approaches responsible for this contradictory association between fiscal decentralization and environmental quality. One is the "Race to Bottom" hypothesis, and the other one is the "Race to Top" hypothesis. Fiscal decentralization is a major determinant of environmental degradation (X. Liu et al., 2017a; Que et al., 2018), and the "Race to Bottom" hypothesis is responsible for the positive association where governments encourage the relaxation of environmental regulatory norms, resulting in a reduction in environmental quality (X. Chen \& Chang, 2020; L. Liu et al., 2019; K. Zhang et al., 2017). On the contrary, Hao et al. (2020), S. Cheng et al. (2020), and K. Li et al. (2020) believe 
that the "Race to the Top" hypothesis is responsible for the negative association between fiscal decentralization and environmental degradation.

Green energy is an essential factor in evaluating environmental sustainability. The gradual shift from non-renewable to renewable energy solutions leads to continuous improvement in environmental sustainability. Thus to promote renewable energy and ecofriendly energy consumption is need of the hour to achieve economic-cum-environmental goals and objectives (Charfeddine \& Kahia, 2019; de Souza et al., 2018; Lau et al., 2018; Ridzuan et al., 2020; Riti \& Shu, 2016; Samuel Asumadu Sarkodie et al., 2020; Sharif et al., 2019; Z. Wang et al., 2018; K. Zhang et al., 2017).

Apart from the role of fiscal decentralization and green energy, economic policy uncertainty has gained the central position in economic-cum-environmental objectives (Baker et al., 2016). Thus, the ambiguity surrounding governmental policies, particularly fiscal and monetary policies, that affects the economic environment in which businesses operate is called (EPU) economic policy uncertainty (Pirgaip \& Dinçergök, 2020). However, COVID-19 has recently produced a great deal of economic uncertainty worldwide (Altig et al., 2020). Literature shows the positive association between environmental degradation and monetary policy uncertainty and determines that economic policy uncertainty is a significant and positive determinant of ecological degradation (Adams et al., 2020; Jiang et al., 2019; Q. Wang et al., 77 2020).

However, the current literature can be criticized for failing to capture the whole aspects of a sustainable environment because of the extensive use of $\mathrm{CO} 2$ emission as a proxy. This proxy has recently been questioned because it is not comprehensive as the individual impact on the environment is not considered. As a result, the focus has switched to ecological footprint as a superior proxy (Ahmed et al., 2020; Andrew A Alola, 2019; Andrew Adewale Alola \& Alola, 2018; Andrew Adewale Alola, Bekun, et al., 2019; Baccini \& Brunner, 2012; Barrett \& Scott, 2003; Bello et al., 2018; Charfeddine \& Mrabet, 2017; Dogan et al., 2019; S. Nathaniel \& Khan, 2020; Ulucak \& Bilgili, 2018J. Wang \& Dong, 2019; Zahra et al., 2021). The ecological footprint combines the two concepts to address the damage caused by human activities at the ground level and the damage caused by the unreturned use of all of the Earth's natural resources. 
88 Moreover, the ecological footprint is also regarded as a measure of environmental sustainability

89 (Destek \& Sinha, 2020).

90 The core objective of this study is to empirically investigate the impact of green energy, 91 economic policy uncertainty, and asymmetric effects of fiscal decentralization on the ecological

92 footprint in the United States of America, United Kingdom, Germany, Australia and Canada, the 93 OECD counties, as explained in Fig: 1. These countries are highly decentralized OECD countries 94 in which Germany, Australia, and Canada, during the last three decades, shifted from centralized 95 to highly decentralized status. Even these three countries are included in the top seven 96 decentralized countries, which have an average fiscal decentralization ratio of more than $58 \%$ in 97 2018, greater than the average ratio of fiscal decentralization of the rest of the world (Shan et al., 98 2021). Secondly, while keeping the effects of environmental convergence in mind; the USA is $992^{\text {nd }}$ top $\mathrm{CO}_{2}$ emitter in the World, while Australia, Germany and Canada are included in the list 100 of top fifteen $\mathrm{CO}_{2}$ emitters of the World. Thirdly, these developed countries can achieve SDGs to 101 bring forward socio-political and environmental economic objectives and synergy (Destek \& 102 Sinha, 2020). These reasons create room to investigate the association between fiscal 103 decentralization, clean energy, economic policy uncertainty, and environmental sustainability in 104 these five selected OECD countries. 


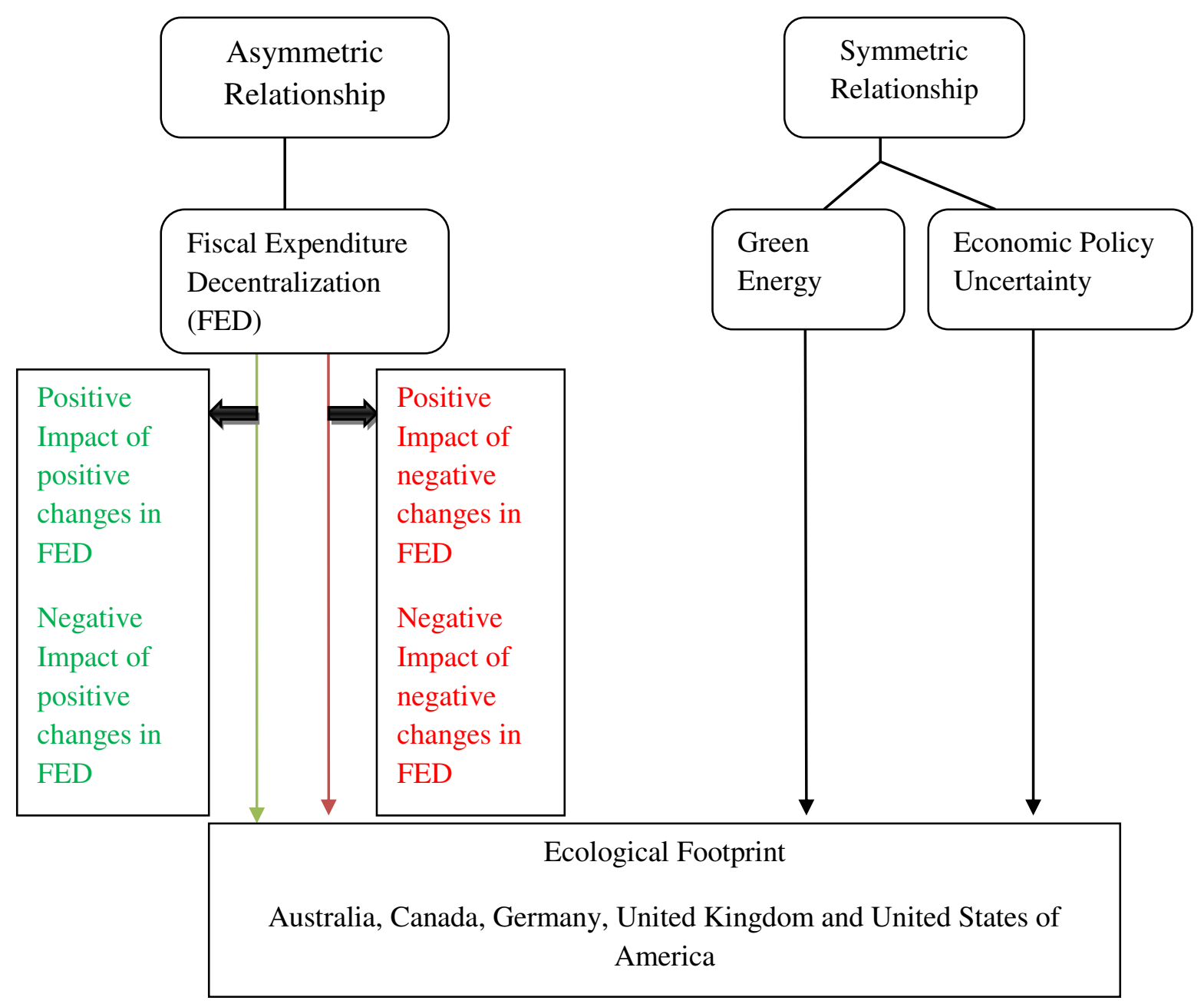

Fig.1 Objectives of the study

The current study adds to the previous literature in two ways. First, most research in the 109 literature has analyzed the symmetrical empirical association between fiscal decentralization and 110 the environment, using variables such as fiscal expenditure decentralization and fiscal revenue 111 decentralization, and environmental emissions. The present study fills the existing gap by 112 determining the asymmetric or nonlinear impact of fiscal expenditure decentralization on 113 environmental sustainability for selected OECD countries. Secondly, most previous research 114 studies employed CO2 emissions as a proxy for environmental degradation; this study 115 approximates the ecological footprint to measure environmental quality. 
Moreover, Policymakers, environmentalists, and government officials will benefit from the results of this study, which provide a deeper understanding and critical information, consequences, and evidence for environmental protection. The literature on fiscal decentralization, green energy, and economic policy uncertainty concerning their impact on the environment is briefly examined in section 2 . We cover the model, data, and methodology in section 3. Empirical findings and their interpretation will be discussed in section 4. Finally, we conclude the results and policy implications in section 5.

\section{Literature Review}

\subsection{Fiscal Decentralization and Environmental Degradation}

Fiscal decentralization is a practice in which regional or provincial governments are given allocated authority or control over the regional economic activity (Hao et al., 2020; L. Liu et al., 2019). Therefore, fiscal decentralization has been documented as a global trend during the past several decades (L. Wang \& Lei, 2016). Furthermore, studies indicate that fiscal decentralization can, directly and indirectly impact environmental quality (Li et al., 2021). The research shows as fiscal decentralization draw its impact on economic growth and development, which in return draws its influence on environmental quality and environmental degradation. Thus there is an indirect correlation between environmental quality and fiscal decentralization. Contrary, the literature also demonstrates that fiscal decentralization directly impacts environmental protection and quality. Shi et al. (2018); L. Wang and Lei (2016) and $\mathrm{H}$. Chen et al. (2018) positively associate fiscal decentralization with environmental degradation and determine fiscal decentralization decline the environmental quality, thus improving environmental pollution. Similarly, C. He et al. (2012), Sigman (2007); J. Liu et al. (2017); Que et al. (2018); Kuai et al. (2019); Esty (1996); Ljungwall and Linde-Rahr (2005); Kunce and Shogren (2008); Taguchi and Murofushi (2010); Batterbury and Fernando (2006); Sigman (2014); Fell and Kaffine (2014) empirically investigated that fiscal decentralization is a major factor for promoting environmental degradation.

There is no consensus in the literature about the association between fiscal decentralization and environmental degradation. K. Zhang et al. (2017) and X. Chen and Chang (2020) have opinioned that the "Race to the Bottom" hypothesis is responsible for a positive association 
between environmental degradation and fiscal decentralization. On the contrary, Hao et al. (2020), S. Cheng et al. (2020), and K. Li et al. (2020) believe that the "Race to the Top" hypothesis is responsible for the negative association between fiscal decentralization and environmental degradation. As a result, investigating the influence of nonlinear fiscal decentralization on environmental quality is required to develop a strong policy framework (Shan et al., 2021).

\subsection{Green Energy and Environmental Degradation}

The gradual shift from non-renewable to renewable energy solutions leads to continuous improvement in ecological quality. Ozturk et al. (2016); Esso and Keho (2016); Bekhet et al. (2017); (Baloch, Zhang, et al., 2019); Charfeddine and Mrabet (2017); Baloch, Zhang, et al. (2019); Ozcan et al. (2020); and C.-Z. Chen and Lin (2008) empirically investigated a positive relationship between non-renewable energy consumption and ecological footprint as it is the major determinant responsible for increasing environmental footprint. Similarly, B. Chen et al. (2007) for China between 1981 and 2001, Caviglia-Harris et al. (2009) for selected 146 countries between 1961 and 2000, and Al-Mulali et al. (2016) for selected 144 countries in 1988 till 2008 determine that primary energy or non-renewable energy consumption is the major determinant of ecological footprint. Considering the importance of green energy in the arena of ecological footprint, certain studies also investigate the importance of renewable energy consumption to control the burden on ecological footprint. Sarkodie et al. (2020); Destek and Sarkodie (2019); Dogan et al. (2019); Ozcan et al. (2018); Bello et al. (2018) and Destek et al. (2018) empirically investigated that green energy is a significant determinant to reduce the ecological footprint and thus promote environmental quality. Similarly, Destek and Sinha (2020) for twenty-four OECD countries empirically investigated that increasing green energy reduces pressure on ecological footprint and vice versa. Similarly, Pata (2021) for BRICS countries between time period of 1971 and 2016 determines that renewable energy consumption reduces ecological footprint. Similarly; Usman et al. (2020) by using ARDL model for quarterly data from 1985:Q1 to 2014:Q4 determines for USA that renewable energy exerts negative pressure on increase in ecological footprint. On the contrary; Nathaniel et al. (2020) for MENA countries in time span of 1990 to 2016 empirically investigated that green energy does not contribute to the environmental quality. 
177 Economic Policy Uncertainty may have environmental consequences in addition to its financial 178 products. EPU may compel producers to use inefficient and environmentally damaging 179 production methods, hence increasing CO2 emissions. Furthermore, EPU may impact consumption and investment, resulting in lower CO2 emissions (Anser et al., 2021). Literature such as Pirgaip and Dinçergök (2020); Q. Wang et al. (2020); Ulucak and Khan (2020); Yu et al. (2021); Anser et al. (2021) shows the positive association between environmental degradation and economic policy uncertainty and determine that economic policy uncertainty is major and positive determinant environmental degradation. Similarly, Jiang et al. (2019) investigated that economic policy uncertainty in the USA is an economic problem that diverts Government attention from environmental burning concerns and thus causes indirect degradation to the environment and reduces environmental quality. In addition Adams et al. (2020) by replacing Economic Policy Uncertainty with World Uncertainty Index as a proxy of uncertainty empirically investigated that it is the major determinant responsible to escalate environment deterioration and $\mathrm{CO}_{2}$ emission. On the other hand, Adedoyin and Zakari (2020) depicts that economic policy uncertainty increases environmental quality in the short run and then ultimately ecological degradation in the long run.

\section{Research Methodology}

\subsection{The Model}

The paper aims to empirically investigate the asymmetric imoact of fiscal decentralization on ecological footprint. We exhibit the ecological footprint as a function of fiscal decentralization, green energy, and economic policy uncertainty as given below: 
Mathematically:

$$
E F P_{t}=\alpha_{0}+\alpha_{1} F E D_{t}+\alpha_{2} G E_{t}+\alpha_{3} E P U_{t}+e_{t}
$$

207 Where $\mathrm{t}$ shows each quarter of the selected data as subscripts and $\alpha_{0} \ldots \alpha_{3}$ are respective parameter coefficients. The dependent variable is anticipated to respond to both increases and decreases of each independent variable in the traditional cointegration (Badeeb \& Lean, 2018). Linear Unrestricted Error Correction Model (UECM) without asymmetry or nonlinear impact, both in the long run and short run, is shown in Equation 3 with $\alpha_{i}$ and $\beta_{i}$ as short run and longrun parameters, respectively. On the other hand, $e_{t}$ shows the residual term with mean is equal to zero and constant variance.

$$
\begin{aligned}
& \Delta E F P_{t}=\alpha_{0}+\sum_{k=1}^{m} \alpha_{1} \Delta E F P_{t-k}+\sum_{k=0}^{m} \alpha_{2} \Delta F E D_{t-k}+\sum_{k=0}^{m} \alpha_{3} \Delta G E_{t-k}+\sum_{k=0}^{m} \alpha_{4} \Delta E P U_{t-k}+ \\
& \beta_{1} F E D_{t-1}+\beta_{2} G E_{t-1}+\beta_{3} E P U_{t-1}+e_{t}
\end{aligned}
$$

\subsection{The Methodology}

216 The rapid response of ecological footprint concerning fluctuations in fiscal expenditure decentralization in selected OECD countries could be a hint of asymmetric relationship in the short term, while fluctuation may cause consistent impact in the long run. Following Shin et al.

219 (2014) through asymmetric modification in linear long-run and short-run empirical analysis, $220 F E D_{t}$ is decomposed into partial sum of two new time series variables of each of the variable. As 221 it is noted that there is a contradiction about the role of fiscal decentralization in improving 222 environmental quality and sustainability, particularly as "Race to the Top" hypothesis and "Race 223 to the Bottom" hypothesis; there is an asymmetric association between environment and fiscal 224 decentralization ( $\mathrm{Li}$ et al., 2021). More specifically, one determines the partial sum of positive 225 changes in FED that is $F E D_{t}^{+}$and another one is $F E D_{t}^{-}$as partial sum of negative fluctuations in 226 Fiscal Expenditure Decentralization. The specification is given below in Equations 4 and 5.

$$
\begin{aligned}
& F E D_{t}^{+}=\sum_{m=1}^{t} \Delta F E D_{t}^{+}=\sum_{m=1}^{t} \max \left(F E D_{t}^{+}, 0\right) \\
& F E D_{t}^{-}=\sum_{m=1}^{t} \Delta F E D_{t}^{-}=\sum_{m=1}^{t} \max \left(F E D_{t}^{-}, 0\right)
\end{aligned}
$$


Equation 6 shows the Asymmetric Error Correction Model (AECM), which inserts partial sum of positive and negative fluctuations of fiscal expenditure decentralization as $F E D_{t}^{+}$and $F E D_{t}^{-}$to determine the long-run and short-run asymmetric or nonlinear impact of fiscal decentralization of expenditures on the ecological footprint in selected OECD countries.

$$
\Delta E F P_{t}=\alpha_{0}+\sum_{k=1}^{m} \alpha_{1} \Delta E F P_{t-k}+\sum_{k=0}^{m}\left(\alpha_{2}^{+} \Delta F E D_{t-k}^{+}+\alpha_{2}^{-} \Delta F E D_{t-k}^{-}\right)+\sum_{k=0}^{m} \alpha_{3} \Delta G E_{t-k}+
$$

$$
\sum_{k=0}^{m} \alpha_{4} \Delta E P U_{t-k}+\beta_{1} E F P_{t-1}+\beta_{2}^{+} F E D_{t-1}^{+}+\beta_{2}^{-} F E D_{t-1}^{-}+\beta_{3} G E_{t-1}+\beta_{4} E P U_{t-1}+e_{t}
$$

Wald test can be used to test the long-run symmetry in the model (Badeeb \& Lean, 2018; Li et al., 2021) where the null hypothesis is $\beta_{2}^{+}=\beta_{2}^{-}$. The short-run positive and negative fluctuations or shocks in FED are shown by the coefficient $\alpha_{2}^{+}$and $\alpha_{2}^{-}$, respectively. The Wald test can also be used to determine the short-run asymmetric impact with the null hypothesis of $\alpha_{2}^{+}=\alpha_{2}^{-}$(Atil et al., 2014; Badeeb \& Lean, 2018; Li et al., 2021).

It is important to note that Equation no 3 interprets linear short-run and long-run determinants of ecological footprint (ARDL model) while Equation no 6 determines asymmetric or nonlinear short-run and long-run determinants of ecological footprint in selected five OECD countries. It determines NARDL (nonlinear ARDL) as it includes the model's short-run and long-run partial sum of positive and negative fluctuations.

Finally, appropriate diagnostic tests are used to determine the reliability, stability, and predictability of NARDL coefficients of the model. The Breusch -Godfrey LM test (Breusch, 1978; Godfrey, 1978) was used to verify the residuals auto-correlation and serial correlation. Ramsey's RESET test (Ramsey, 1969) was used to verify the normal distribution of the residual terms and the appropriate functional form of the model. Auto-correlation and $\mathrm{ARCH}$, i.e., Autoregressive Conditional Heteroscedasticity (Engle, 1982), is used to check the residuals.

\subsection{Data Description}

Annual time series data for the variables of this study has been taken from 1998 to 2017 and is converted to quarterly time-series data by using the quadratic match sum method. The quadratic match sum method for converting the data from low frequency to high frequency is a good technique to reduce variations in the data and thus solves the problems related to seasonal variations (M. Cheng et al., 2012; Faisal et al., 2018; Türsoy \& Faisal, 2018); moreover, it also 
256 enhances the long-run relationship investigation between exogenous variables and dependent

257 variable (Kisswani et al., 2020). A time series quarterly data has been taken from 1998 quarter

258 one to 2017 quarter four. All variables are subjected to the natural logarithm. Total three

259 exogenous variables are examined to explore their impact on ecological footprint, which are

260 further explained in Table. 1

261 Table 1: Description of variables

\begin{tabular}{lll}
\hline Variables & Description & Source \\
\hline EP & Ecological Footprint in million gha & Global Footprint Network \\
FED & The ratio of own spending to general & International Monetary Funds \\
& government expenditures & \\
GE & Renewable energy consumption $\%$ of total & WDI 2020 \\
& final energy consumption & \\
EPU & Quarter-wise arithmetic mean of $E P U_{M}$ & Economic Policy Uncertainty \\
& where & Index \\
& $E P U_{M}=\frac{3 C G P U_{3 c-2}+2 C G P U_{3 c-1}+C G P U_{3 c}}{2}$ & www.policyuncertainty.com \\
& Uncertainty where $\mathrm{C}$ shows Cyclical. &
\end{tabular}

262

263 Fiscal expenditure decentralization is an important measure to determine the political risk (Su et $264 a l ., 2021$ ), which is a ratio of provincial expenditures to general government expenditure (Su et 265 al., 2021; K.-H. Wang et al., 2021). However, the environmental impact of political 266 decentralization has remained an important factor (Hao et al., 2020) where local and provincial 267 governments are given the authority to control the economic activities in the allocated area 268 (Farzanegan \& Mennel, 2012; Hao et al., 2020; L. Liu et al., 2019). Renewable energy collected 269 from renewable energy resources such as wind, waves, geothermal, solar, heat, and rain is also 270 called green energy. Green energy is environment friendly and has significant economic benefits, 271 energy security, and reducing climate change (Zandi \& Haseeb, 2019). Green energy 272 consumption as a percentage of total final energy consumption is another exogenous variable of 
273 this study to determine the impact on the ecological footprint in selected OECD countries.

274 Economic policy uncertainty is unpredictably linked with regulatory authorities, fiscal and

275 monetary policies, which can affect economic short-run and long targets and also has sustainable

276 environmental consequences (Adedoyin \& Zakari, 2020). The economic policy uncertainty in

277 this research paper is news based economic policy uncertainty. Baker et al. (2016) developed

278 news based economic policy uncertainty by calculating the proportion of news articles showing

279 policy uncertainty about fiscal and monetary policies, health care facilities, laws and order

280 situation, trade policy, debt, and currency uncertainty (Azqueta-Gavaldón, 2017). These

281 measures concern newspaper credibility, impartiality, biasness, and consistency when measuring

282 policy uncertainty (Amin \& Dogan, 2021).

283

284

285

286

287

288

289

290

291

292

293

294

295

296

297

298

299

300

301

\section{Model Estimation and Result Analysis 4.1. Unit Root}

The pre-requisite to using NARDL to investigate the asymmetric impact of exogenous variables on ecological footprint is to test the time series data for stationarity. It is important to note that NARDL models are employed after checking whether all the variables are stationarity at level or first difference or the mixture of I(0) and I(1). However; if any independent variable is found stationary at the second difference $\mathrm{I}(2)$ or higher difference order; the NARDL is not an appropriate choice to empirically investigate the asymmetric relationship between exogenous and dependent variables of the model; in other words, it will give spurious results (Badeeb et al., 2021; Ibrahim, 2015). In this study, Clemente et al. (1998) structural break unit root is used to check the unit root in the data with one structural breakpoint. The test follows two models: an additive outlier (AO) and an Innovative Outlier (IO). The first model, the addictive outlier model, covers abrupt changes or fluctuations. In contrast, the second one covers the gradual or incremental changes in the mean of the variables in the model. In this case, the AO model prefers to judge the stationary decision because of sudden or abrupt structural changes rather than gradual or show fluctuations. Table 2 shows the outcomes of Clemente et al. (1998) unit root test and determines that none of the variables is stationary at the second difference, which satisfies the pre-requisite condition to use the NARDL model for further analysis.

Table 2: Results of Unit root test with one structural break 


\begin{tabular}{|c|c|c|c|c|c|c|c|c|}
\hline \multirow[t]{3}{*}{ Variables } & \multicolumn{4}{|c|}{ Innovative Outlier } & \multicolumn{4}{|c|}{ Additive Outlier } \\
\hline & \multicolumn{2}{|c|}{ Level } & \multicolumn{2}{|c|}{$1^{\text {st }}$ Difference } & \multicolumn{2}{|c|}{ Level } & \multicolumn{2}{|c|}{$1^{\text {st }}$ Difference } \\
\hline & t-Stats & $\mathrm{TB}$ & t-Stats & $\mathrm{TB}$ & t-Stats & $\mathrm{TB}$ & t-Stats & $\mathrm{TB}$ \\
\hline $\mathrm{EP}$ & -3.63 & 2011Q1 & $-5.74 *$ & 2016Q3 & -3.81 & 2010Q3 & $-7.51 *$ & 2016Q3 \\
\hline FED & $-6.36^{*}$ & 2003Q4 & -- & -- & $-12.23 *$ & 2003Q2 & -- & -- \\
\hline GE & $-4.92 * *$ & 2002Q1 & -- & -- & -4.48 & 2001Q3 & $-5.76^{*}$ & 2015Q2 \\
\hline EPU & $-5.49 *$ & $2007 Q 4$ & -- & -- & $-5.60 *$ & 2007Q4 & -- & -- \\
\hline \multicolumn{9}{|c|}{ Canada } \\
\hline \multirow[t]{3}{*}{ Variables } & \multicolumn{4}{|c|}{ Innovative Outlier } & \multicolumn{4}{|c|}{ Additive Outlier } \\
\hline & \multicolumn{2}{|c|}{ Level } & \multicolumn{2}{|c|}{$1^{\text {st }}$ Difference } & \multicolumn{2}{|c|}{ Level } & \multicolumn{2}{|c|}{$1^{\text {st }}$ Difference } \\
\hline & t-Stats & TB & t-Stats & TB & t-Stats & TB & t-Stats & TB \\
\hline EFP & $-4.94 * *$ & 2002Q4 & -- & -- & $-4.7 * * *$ & 2002Q2 & -- & -- \\
\hline FED & -2.73 & 2014Q4 & $-9.28 *$ & 2014Q1 & -3.07 & 2014Q4 & $-9.20 *$ & 2015Q3 \\
\hline $\mathrm{GE}$ & $-5.57 *$ & 2015Q1 & -- & -- & $-5.76^{*}$ & 2014Q3 & -- & -- \\
\hline EPU & $-4.95 * *$ & 2008Q3 & -- & -- & $-5.0 * *$ & 2008Q2 & -- & -- \\
\hline \multicolumn{9}{|c|}{ Germany } \\
\hline \multirow[t]{3}{*}{ Variables } & \multicolumn{4}{|c|}{ Innovative Outlier } & \multicolumn{4}{|c|}{ Additive Outlier } \\
\hline & Level & & \multicolumn{2}{|c|}{$1^{\text {st }}$ Difference } & Level & & \multicolumn{2}{|c|}{$1^{\text {st }}$ Difference } \\
\hline & $\mathrm{t}$-Stats & $\mathrm{TB}$ & t-Stats & $\mathrm{TB}$ & $\mathrm{t}$-Stats & $\mathrm{TB}$ & t-Stats & TB \\
\hline EFP & $-7.1^{*}$ & 2005Q4 & -- & -- & $-6.7 *$ & 2005Q4 & -- & -- \\
\hline FED & -4.43 & 2012Q2 & $-6.85^{*}$ & 2010Q1 & -4.58 & 2012Q2 & $-6.70^{*}$ & 2016Q3 \\
\hline GE & -4.43 & 2000Q2 & $-8.21 *$ & 2017Q2 & -4.54 & 2000Q2 & $-8.37 *$ & 2017Q1 \\
\hline EPU & $-6.56^{*}$ & 2003Q1 & -- & -- & $-6.66^{*}$ & 2003Q2 & -- & -- \\
\hline \multicolumn{9}{|c|}{ UK } \\
\hline \multirow[t]{3}{*}{ Variables } & \multicolumn{4}{|c|}{ Innovative Outlier } & \multicolumn{4}{|c|}{ Additive Outlier } \\
\hline & Level & & $1^{\text {st }}$ Diffe & ence & Level & & $1^{\text {st }}$ Diffe & nce \\
\hline & $\mathrm{t}-$ Stats & $\mathrm{TB}$ & t-Stats & $\mathrm{TB}$ & t-Stats & $\mathrm{TB}$ & t-Stats & $\mathrm{TB}$ \\
\hline EFP & -3.65 & 2009Q1 & $-6.80 *$ & 2001Q1 & -3.51 & 2008Q3 & $-6.68 *$ & 2011Q1 \\
\hline FED & 3.67 & 2009Q1 & $-8.79 *$ & 2000Q1 & -3.48 & 2001Q2 & $-8.44 *$ & 1999Q2 \\
\hline GE & $-5.22 * *$ & 2012Q1 & -- & -- & $-4.8 * * *$ & $2011 Q 3$ & -- & -- \\
\hline EPU & $-5.31 * *$ & 2016Q1 & -- & -- & -5.22 & $2015 \mathrm{Q} 4$ & -- & -- \\
\hline & & & & USA & & & & \\
\hline Variables & & Innovati & e Outlier & & & Additiv & Outlier & \\
\hline & Level & & $1^{\text {st }}$ Diffe & ence & Level & & $1^{\text {st }}$ Diffe & nce \\
\hline & $\mathrm{t}-$ Stats & $\mathrm{TB}$ & t-Stats & $\mathrm{TB}$ & t-Stats & $\mathrm{TB}$ & t-Stats & $\mathrm{TB}$ \\
\hline EFP & -4.50 & 2010Q2 & $-7.16^{*}$ & 2009Q1 & -4.21 & 2010Q2 & $-7.74 *$ & 2008Q2 \\
\hline FED & -3.67 & 2009Q1 & $-8.79 *$ & 2000Q1 & -3.48 & 2001Q2 & $-8.44 *$ & 1999Q2 \\
\hline GE & -4.53 & 1999Q1 & $-8.56^{*}$ & 2001Q1 & -3.80 & 1998Q4 & -8.11 & 2001Q1 \\
\hline EPU & $-5.0 * *$ & 2003Q2 & -- & -- & $-5.15 * *$ & 2003Q2 & -- & -- \\
\hline
\end{tabular}

$*, * *, * * *$ denotes $1 \%, 5 \%$ and $10 \%$ level of significance. 
305 It is important to note that the choice of lag order is receptive to selecting the optimal lag length 306 for the NARDL model. There are different selection measures used to determine the most 307 suitable lag length. Due to the limited number of observations, lag length can be imposed to an 308 appropriate, limited number (Badeeb et al., 2020). Here we assess three lags of each of the first 309 differences of the variables. The Wald test is used to judge the presence of the long-run and 310 short-run symmetric and asymmetric relationship between an exogenous variable and ecological 311 footprint (Badeeb \& Lean, 2018; Jafri et al., 2021; Li et al., 2021). Table 3 exhibits long-run 312 asymmetric relationship in Australia and USA, short-run asymmetric relationship in Canada and 313 Germany, and symmetric relationship in the UK both in the long run and short run between fiscal 314 expenditure decentralization and ecological footprint for the respective countries.

316 Table 3: Wald Test for Short Run and Long Run Symmetry

\begin{tabular}{llll}
\hline & Long Run $W_{L R}$ & Short Run $W_{S R}$ & Selected Specification \\
\hline Australia & $4.356^{* *}$ & 1.154 & NARDL with LR Asymmetry \\
Canada & $(0.04)$ & $(0.287)$ & \\
& 0.05 & $2.93^{* * *}$ & NARDL with SR Asymmetry \\
Germany & $(0.821)$ & $(0.09)$ & \\
& 0.087 & $4.3 * *$ & NARDL with SR Asymmetry \\
UK & $(0.786)$ & $(0.04)$ & \\
& 1.81 & 0.20 & Symmetry (ARDL) \\
USA & $(0.18)$ & $(0.75)$ & \\
& $3.87^{* *}$ & 0.0006 & NARDL with LR Asymmetry \\
\hline 17 & $(0.05)$ & $(0.97)$ & \\
\hline
\end{tabular}

$317 *, * *, * * * 1 \% 5 \% 10 \%$ level of significance. Probability values are in parenthesis

318

319

320

321

322

323

324

325

\subsection{Main Results and Discussion}

\subsubsection{Empirical Results}

As indicated in Table 4, the analysis empirically discusses these countries' long and short-run dynamics one by one.

\subsubsection{Australia}

Wald test supports a long-run asymmetric and short-run symmetric relationship by depicting the long-run positive relationship between the partial sum of positive changes in fiscal 
expenditure decentralization and ecological footprint. At the same time, the partial sum of negative changes is not a substantial determinant of ecological footprint in the long run. At the same time, green energy is the negative determinant of an ecological footprint both in the long and short run. Contrary, the economic policy uncertainty is not a substantial determinant of ecological footprint in both periods. Jiang et al. (2019) also empirically concluded that EPU is not the major determinant of carbon emission in the commercial sector.

\subsubsection{Canada}

The result depicts a short-run, negative, but significant relationship between the partial sum of positive changes in fiscal expenditure decentralization and ecological footprint in Canada. Contrary, there is a long-run positive and symmetric relationship between these two variables. Unlike Australia, in this country, green energy is neither a significant factor of ecological footprint in the long run nor in the short run. Likewise, economic policy uncertainty is not a substantial factor in an ecological footprint both in the long and short run.

\subsubsection{Germany}

Table. 4 suggests that the partial sum of adverse changes in fiscal expenditure decentralization is the positive short-run determinant of an ecological footprint as the Wald test determines the short-run asymmetry between them. Likewise, fiscal expenditure decentralization has a negative but symmetric relationship with the ecological footprint in the long run. On the other hand, green energy is only a long-run negative determinant that suggests replacing green energy with non-renewable energy in the long run to reduce environmental pressure in the country. Moreover, economic policy uncertainty is a negative but significant factor of an ecological footprint both in the long and short run.

\subsubsection{United Kingdom}

As per the Wald test and ARDL model, a symmetric, significant and positive relationship is found between fiscal expenditure decentralization and ecological footprint in the long and short run. Contrary, green energy is neither a significant variable of ecological footprint in 
the long run nor the short run. On the other hand, economic policy uncertainty is a negative

354 but significant determinant of ecological footprint in the long run only.

355

356

357

358

359

360

361

362

363

364

365

366

\subsubsection{United States of America}

Like Australia, the Wald test confirms long-run asymmetry between fiscal expenditure decentralization and ecological footprint in the USA. Positive changes in expenditure decentralization are positive long-term determinants of ecological footprint; contrary, with no influence in the short run. Moreover, green energy is the negative determinant of ecological footprint in the short-run and the long-run. Therefore, in the United States of America increase in green energy for production and consumption purpose is suggested to reduce the ecological pressure. While economic policy uncertainty is a negative but significant determinant of an ecological footprint both in the long and short run. While economic policy uncertainty is a negative but significant factor or determinant of an ecological footprint both in the long and short run.

Table 4: Nonlinear ARDL estimation results

\begin{tabular}{|c|c|c|c|c|c|}
\hline \multirow{2}{*}{\multicolumn{2}{|c|}{$\begin{array}{l}\text { Australia } \\
\text { NARDL with LR Asymmetry }\end{array}$}} & \multicolumn{2}{|c|}{ Canada } & \multicolumn{2}{|c|}{ Germany } \\
\hline & & \multicolumn{2}{|c|}{ NARDL with SR Asymmetry } & \multicolumn{2}{|c|}{ NARDL with SR Asymmetry } \\
\hline $0{ }^{\prime} 1 ;$ & $\begin{array}{l}3.66^{* *} \\
(2.04)\end{array}$ & $F E D_{t-1}$ & $\begin{array}{c}0.83^{* * * *} \\
(1.80)\end{array}$ & $F E D_{t-1}$ & $\begin{array}{l}-3.96^{* *} \\
(-2.14)\end{array}$ \\
\hline$F E D_{t-1}^{-}$ & $\begin{array}{l}2.92 \\
(1.9)\end{array}$ & -- & & -- & -- \\
\hline$G E_{t}$ & $\begin{array}{l}0.03 *^{-} \\
2.52)\end{array}$ & $G E_{t-1}$ & $\begin{array}{c}-0.0008 \\
(-0.05)\end{array}$ & $G E_{t-1}$ & $\begin{array}{l}0.0003 \\
(0.07)\end{array}$ \\
\hline$E P U_{t}$ & $\begin{array}{r}-0.0035 \\
(-0.78)\end{array}$ & $E P U_{t-1}$ & $\begin{array}{l}-0.006 \\
(-1.26)\end{array}$ & $E P U_{t-1}$ & $\begin{array}{l}-0.013^{*} \\
(-2.76)\end{array}$ \\
\hline$\triangle F E D_{t}$ & $\begin{array}{c}-2.55 \\
(-0.80)\end{array}$ & $\Delta F E D_{t}^{+}$ & $\begin{array}{c}- \\
18.05^{*} \\
(2.85)\end{array}$ & $\triangle F E D^{+}$ & $\begin{array}{r}-1.61 \\
(0.32)\end{array}$ \\
\hline$\Delta F E D_{t-1}$ & $\begin{array}{c}2.60 \\
(0.63)\end{array}$ & -- & -- & $\Delta F E D_{t-1}^{+}$ & $\begin{array}{c}3.18 \\
(0.69)\end{array}$ \\
\hline & & $\Delta F E D_{t}^{-}$ & $\begin{array}{c}8.52 \\
(0.81)\end{array}$ & $\triangle F E D^{-}$ & $\begin{array}{c}9.21 \\
(1.50)\end{array}$ \\
\hline & & $\Delta F E D_{t-1}^{-}$ & $\begin{array}{l}5.47 \\
(0.5)\end{array}$ & $\Delta F E D_{t-1}^{-}$ & $\begin{array}{l}16.13^{* * *} \\
(2.24)\end{array}$ \\
\hline$\Delta G E_{t}$ & $\begin{array}{c}-0.11 * * \\
(-2.34)\end{array}$ & $\Delta G E_{t}$ & $\begin{array}{c}-0.034 \\
-0.81\end{array}$ & $\Delta G E$ & $\begin{array}{l}-0.09 * \\
(-3.73)\end{array}$ \\
\hline
\end{tabular}




\begin{tabular}{|c|c|c|c|c|c|}
\hline$\Delta E P U_{t}$ & $\begin{array}{c}0.0004 \\
(0.08)\end{array}$ & $\begin{array}{c}\Delta G E_{t-1} \\
\Delta E P U \\
--\end{array}$ & $\begin{array}{c}0.04 \\
(0.041) \\
-0.004 \\
(-0.62) \\
--\end{array}$ & $\begin{array}{c}-- \\
-- \\
\Delta E P U\end{array}$ & $\begin{array}{c}-- \\
-- \\
-0.0084 * * \\
(-1.95) \\
--\end{array}$ \\
\hline Constant & $\begin{array}{l}1.78 * \\
(2.87) \\
\end{array}$ & Constant & $\begin{array}{l}3.04 * \\
(3.57)\end{array}$ & & $\begin{array}{l}5.9 * \\
(5.27)\end{array}$ \\
\hline $\begin{array}{c}\text { Long Run Coefficient } \\
\qquad F E D^{+} \\
L F E D^{-}\end{array}$ & $\begin{array}{l}35.56 * * * \\
-28.57\end{array}$ & $\begin{array}{l}\text { LFED } \\
--\end{array}$ & $4.95 *$ & LFED & $-12.46^{* *}$ \\
\hline $\begin{array}{c}\text { United Kingdom } \\
\text { Symmetric ARDL }\end{array}$ & 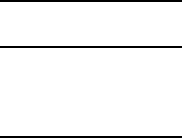 & & & $\begin{array}{l}\text { USA } \\
\text { NARDL with LR } \\
\text { Asymmetry }\end{array}$ & \\
\hline$F E D_{t-1}$ & $\begin{array}{l}1.82 * * * \\
(1.73)\end{array}$ & & & $\begin{array}{l}F E D_{t-1}^{+} \\
F E D_{t-1}^{-}\end{array}$ & $\begin{array}{c}1.53 * * * \\
(1.70) \\
-0.44 \\
(-0.76)\end{array}$ \\
\hline$G E_{t-1}$ & $\begin{array}{l}0.0023 \\
(0.46)\end{array}$ & & & $G E_{t-1}$ & $\begin{array}{l}-0.038 * \\
(-3.18)\end{array}$ \\
\hline$E P U_{t-1}$ & $\begin{array}{c}- \\
0.0067 * * \\
(-2.26)\end{array}$ & & & $E P U_{t-1}$ & $\begin{array}{l}-0.021 * \\
(-3.97)\end{array}$ \\
\hline$\triangle F E D$ & $\begin{array}{c}7.04^{*} \\
(2.81)\end{array}$ & & & $\triangle F E D$ & $\begin{array}{c}-4.12 \\
(-1.56)\end{array}$ \\
\hline-- & -- & & & $\Delta F E D_{t-1}$ & $\begin{array}{c}0.37 \\
(1.54)\end{array}$ \\
\hline$\Delta G E$ & $\begin{array}{c}-0.03 \\
(-0.64)\end{array}$ & & & $\Delta G E_{t}$ & $\begin{array}{l}-0.089 * \\
(-2.40)\end{array}$ \\
\hline$\Delta G E_{t-1}$ & $\begin{array}{c}0.04 \\
(0.82)\end{array}$ & & & -- & -- \\
\hline$\triangle E P U$ & $\begin{array}{l}-0.003 \\
(-0.96)\end{array}$ & & & $\Delta E P U_{t}$ & $\begin{array}{c}-0.009 * * \\
(-2.02)\end{array}$ \\
\hline Constant & $\begin{array}{l}1.51 * \\
(3.10)\end{array}$ & & & Constant & $\begin{array}{c}4.3 \\
(4.86)\end{array}$ \\
\hline LFED & $1.82 * *$ & & & $\begin{array}{l}L_{F E D^{+}} \\
L_{F E D^{-}}\end{array}$ & $\begin{array}{c}7.25^{* *} \\
2.09\end{array}$ \\
\hline
\end{tabular}




\subsubsection{Fiscal Decentralization and Environmental Degradation}

375 A partial sum of positive changes in expenditure decentralization increases the ecological footprint in Australia and USA in the long run. These results are also in-line with Li et al. (2021) at a 5\% level of significance used as an environmental proxy. Li et al. (2021) suggested that in the long-run positive changes of fiscal expenditure decentralization have a positive association with environmental degradation for Pakistan between 1984 and 2018. On the contrary, Yan and Zhong (2012) and K. Zhang et al. (2017) argued that fiscal decentralization could not help control emissions. You et al. (2019) suggested that "Race to Bottom" is the major reason for a positive relationship between fiscal expenditure decentralization and environmental footprint in the long run. Most high-profit enterprises are attracted by decentralized governments that do not impose strong environmental regulations, leading to "Race to Bottom"(You et al., 2019).

On the other hand, Du and Sun (2021) regarded capital competition and biased and partial 386 technological development as a major cause of a nonlinear but positive association between fiscal decentralization and environmental degradation. However, the negative changes in expenditure decentralization are not a significant variable of ecological footprint but also positively associated with an ecological footprint in both countries in the long run. Likewise, Q. He (2015) and Li et al. (2021) investigated the positive but insignificant relationship between fiscal expenditure decentralization and environmental degradation in the long run.

As Table 3 suggests, the symmetric long-run relationship between fiscal expenditure decentralization and ecological footprint in Canada, Germany, and United Kingdom. In Canada and the United Kingdom, fiscal expenditure decentralization is positively interlinked with an ecological footprint in the long run. These results are also in line with previous literature such as L. Liu and Li (2019), You et al. (2019), Du and Sun (2021), Li et al. (2021); Shan et al. (2021) and Y. Cheng et al. (2021) as these studies show a positive relationship between fiscal decentralization and environmental degradation in the long run. Shan et al. (2021) confirm the typical inverted U-shaped relationship between environmental degradation and fiscal decentralization for seven selected OECD countries. The potential reason is local or decentralized governments, while keeping GDP growth in mind, attract relatively cheaper and 
expenses of environment sustainability. Therefore this "Race to Bottom Hypothesis" is the major cause of positive relationship between environmental degradation and fiscal expenditure decentralization.

The short-run analysis depicts quite interesting output, as shown in Table 4. In Germany, the short-run asymmetric relationship between fiscal expenditure decentralization and ecological footprint is in line with S. Cheng et al. (2020), who determines the nonlinear relationship between fiscal expenditure decentralization and environmental degradation in China. According to S. Cheng et al. (2020) increase in per capita fiscal expenditure decentralization will reduce $\mathrm{CO}_{2}$ emissions in China. Contrary, Li et al. (2021) exert a positive short-run relationship between fiscal expenditure decentralization and ecological footprint in Pakistan. It is interesting to note Shan et al. (2021) depicts both positive and negative short-run relationship between environmental degradation proxy that is $\mathrm{CO}_{2}$ emission and fiscal decentralization in different provinces of China. The research has concluded that the sign of relation coefficient between environment and fiscal decentralization depends on technological progress and energy consumption methods. Therefore fiscal decentralization coupled with technological progress can reduce carbon emission (Shan et al., 2021).

Table 4. shows both short-run and long-run symmetric, significant, and positive relationships between fiscal expenditure decentralization and ecological footprint in the United Kingdom. These results are supported by previous literature. According to L. Liu and Li (2019), the possible explanation is as fiscal decentralization (expenditure decentralization) increases, local governments seeking to maximize their benefits choose to focus on the development of the local economy than improving environmental quality. Such a strategy intensifies pollution in the environment. CO2 emissions also have a significant negative externality; conversely, decarbonization has a significant positive externality. Local governments are interested in free rides to maximize regional economic growth, resulting in a steady increase in carbon emissions. Yang et al. (2020) also investigated the same positive correlation between fiscal expenditure decentralization and environmental degradation for China. It is suggested that local governments avoid the "Free Riding" of resources to boost economic output on the expenses of environmental sustainability. Similarly, L. Liu et al. (2019) and Hao et al. (2020) empirically supported these results. They investigated the positive relationship between fiscal decentralization and 
environmental footprint or environmental degradation at the first stage, empirically proving an inverted $U$ shape relationship between them. These studies have concluded that there is "Race to Bottom Hypothesis" prevailing, which is responsible for deteriorating environmental sustainability at local level.

Result suggests fiscal expenditure decentralization is not the major or significant determinant of ecological footprint in the short run in Australia and the United States of America. These results are also in-line with S. Cheng et al. (2020), who didn't find any significant relationship between fiscal expenditure decentralization and environmental degradation in China between 1995 and 2010. To better comprehend Table. 5 has summarized these results.

Table: 5. Result Summary (Fiscal Expenditure Decentralization and Ecological Footprint)

\begin{tabular}{ccccccc} 
FED Impact & & Australia & Canada & Germany & UK & USA \\
\hline Long Run & Increase in FED & + & $\{+\}$ & $\{-\}$ & $\{+\}$ & + \\
& Decrease in FED & NS & & & & NS \\
Short Run & Increase in FED & $\{$ NS $\}$ & - & NS & $\{+\}$ & $\{-\}$ \\
& Decrease in FED & & NS & + & &
\end{tabular}

NS represents not Significant, \{\} shows symmetric, + and - shows positive and negative relationship respectively.

\subsubsection{Green Energy and Environmental Degradation}

Table. 4 shows renewable energy consumption is a major determinant of ecological footprint in Australia and the United States of America both in the short run and long run. The result also determines the long-run and short-run negative relationship between green energy consumption and ecological footprint in both countries. On the other hand, in the United Kingdom and Canada, green energy consumption is not a major determinant of an ecological footprint both in the short-run and long-run and draws no significant influence on ecological footprint. On the contrary, green energy is a negative determinant of ecological footprint in Germany in the short run but not a significant variable in the long run. Energy-incentive inputs can increase growth, sustainability, and quality (Majeed \& Tauqir, 2020; Zhao et al., 2013). However, non-renewable energy resources deteriorate environmental quality and sustainability (Baloch, 2018; Baloch \& Suad, 2018; Baz et al., 2020; Majeed \& Luni, 2019; Munir \& Riaz, 2020; Pao \& Tsai, 2010, 2011). Similarly, S. Wang et al. (2011) ; Saboori and Sulaiman (2013); Shahbaz et al. (2012); Ozturk and Acaravci (2013); Ahmad et al. (2016); (Bekhet et al., 2017; Esso \& Keho, 2016); Ozturk et al. (2016); Solarin et al. (2017); Mrabet and Alsamara (2017); Atasoy (2017); B. 
Zhang et al. (2017); Alvarado et al. (2018); S. Chen et al. (2019); Sohail et al. (2021); Majeed and Tauqir (2020); also investigated the positive relationship between of non-renewable energy consumption and environmental degradation, on the contrary, the use of renewable energy resources or green energy has reduced environmental pollution and thus decreased $\mathrm{CO}_{2}$ emission to a certain extend (Majeed \& Luni, 2019; Ozturk et al., 2016; Z. Wang et al., 2018; Zhang et al., 2018). Along with these findings Charfeddine (2017), Baloch, Zhang, et al. (2019); (Ozcan et al., 2020), Majeed et al. (2021), and Charfeddine and Mrabet (2017) has explored nonrenewable that an increase in non-renewable energy resource exploitation increases the extent of ecological footprint. On the contrary, Sarkodie et al. (2020); Alola et al. (2019); Baloch, Mahmood, et al. (2019); Dogan and Seker (2016); Dogan and Ozturk (2017); Zaidi et al. (2018); Khan et al. (2020); Vural-Yavaş (2021) ; Swain and Karimu (2020); Chu and Le (2021); Amin and Dogan (2021); Z. Wang et al. (2020); Adams and Acheampong (2019) and Chu and Le (2021) found the solution for this problem and empirically investigated that the use of renewable energy helps to not only control and alleviates $\mathrm{CO}_{2}$ emission but also reduce ecological footprint.

\subsubsection{Economic Policy Uncertainty and Environmental Degradation}

In the long run, in the case of Germany, the UK, and the United States of America, economic policy uncertainty is a negative but significant factor or determinant of ecological footprint, while in the short run, it is significant in Germany and USA only. These results also align with Chu and Le (2021) and Adedoyin and Zakari (2020), who empirically investigated the negative relationship between economic policy uncertainty and environmental degradation. This negative relationship is if EPU draws an effect on volume and pattern of consumption that will surely reduce $\mathrm{CO}_{2}$ emission and ultimately environmental degradation and ecological footprint. To compensate for the low revenue induced by EPU, manufacturers utilize low-cost energy sources in their production methods. As a result, when revenue grows, they use environmentally friendly production methods in such industries, resulting in lower CO2 emissions (Amin \& Dogan, 2021). Similarly, Syed and Bouri (2021) exhibit that EPU increases CO2 emissions in the short run, implying that high EPU is responsible for short-term environmental damage. However, EPU reduces $\mathrm{CO} 2$ emissions in the long run, interpreting that a high EPU improves environmental quality. Given the evidence of a trade-off between EPU and CO2 emissions, authorities should take immediate steps to minimize EPU to improve environmental quality. In the long run, if 
policymakers want to limit EPU and $\mathrm{CO} 2$ emissions simultaneously, they should look for alternative strategies to offset $\mathrm{CO} 2$ emissions (for example, renewable energy consumption). Contrary, Amin and Dogan (2021); Pirgaip and Dinçergök (2020); Adams et al. (2020) ; Q. Wang et al. (2020); Ulucak and Khan (2020); Yu et al. (2021); Anser et al. (2021); Zakari et al. (2021); Adedoyin et al. (2021) empirically investigated that economic policy uncertainty adversely influences the environmental quality and enhance environmental degradation by escalating $\mathrm{CO}_{2}$ emission. The current study further shows that there is a negative relationship between economic policy uncertainty and ecological footprint both in Germany and the USA. While in the case of Australia and Canada, economic policy uncertainty is not the major determinant of ecological footprint both in the short-run and long-run. Jiang et al. (2019) also empirically concluded that in commercial sector EPU is not the major determinant of $\mathrm{CO}_{2}$ emission.

\subsection{Diagnostic Tests}

Finally, different diagnostic tests are applied to confirm whether the coefficients of the selected nonlinear ARDL model are reliable, stable, and predictable or not. The results of the Breusch-Godfrey LM test (Breusch, 1978; Godfrey, 1978) confirmed that the specified nonlinear ARDL model is free from serial correlation problems, as the probability value of $X^{2}$ statistical is insignificant at the significance level of 5\%. The results of the Ramsey's RESET test (Ramsey, 1969) verified the normal distribution of the residual terms, as the probability value of $X^{2}$ statistical is insignificant at the significance level of 5\%. Similarly, the ARCH test suggests that the selected data for all five OECD selected countries are homoscedastic and no evidence of heteroscedaticity is found at 5\% level of significance. Findings of diagnostic tests are given in Table 6.

Table 6. Findings of Diagnostic Tests

\begin{tabular}{lllllllllll} 
& \multicolumn{2}{l}{ Australia } & \multicolumn{2}{l}{ Canada } & \multicolumn{2}{l}{ Germany } & UK & & USA \\
\hline Test & Stats & Prob & Stats & Prob & Stats & Prob & Stats & Prob & Stats & Prob \\
\hline $\begin{array}{l}\text { Breusch-Pagan- } \\
\text { Godfrey LM }\end{array}$ & 0.32 & $0.72^{*}$ & 0.21 & $0.81^{*}$ & 0.02 & $0.89^{*}$ & 0.92 & $0.40^{*}$ & 0.81 & $0.44^{*}$ \\
$\begin{array}{l}\text { Ramsey's } \\
\begin{array}{l}\text { RESET test } \\
\text { ARCH Test }\end{array}\end{array}$ & 2.88 & $0.12 *$ & 0.023 & $0.98^{*}$ & 1.24 & $0.21^{*}$ & 1.0 & $0.31^{*}$ & 2.50 & $0.18^{*}$ \\
$\quad$ & 0.15 & $0.92 *$ & 0.35 & $0.55^{*}$ & 0.09 & $0.75^{*}$ & 0.36 & $0.54^{*}$ & 0.12 & $0.73^{*}$ \\
\hline *5\% level of significance & & & & & & & &
\end{tabular}




\subsection{Cumulative Effects of Fiscal Decentralization, Green Energy and Economic Policy Uncertainty on Ecological Footprint.}

517 The graphical presentation is given in Fig. 2, Fig. 3, Fig. 4, Fig. 5, and Fig. 6 shows the

518 cumulative effect of fiscal decentralization, green energy, and economic policy uncertainty on

519 ecological footprint for Australia, Canada, Germany, UK, and the USA, respectively by

520 determining the positive changes, negative changes and asymmetry in the data.

521
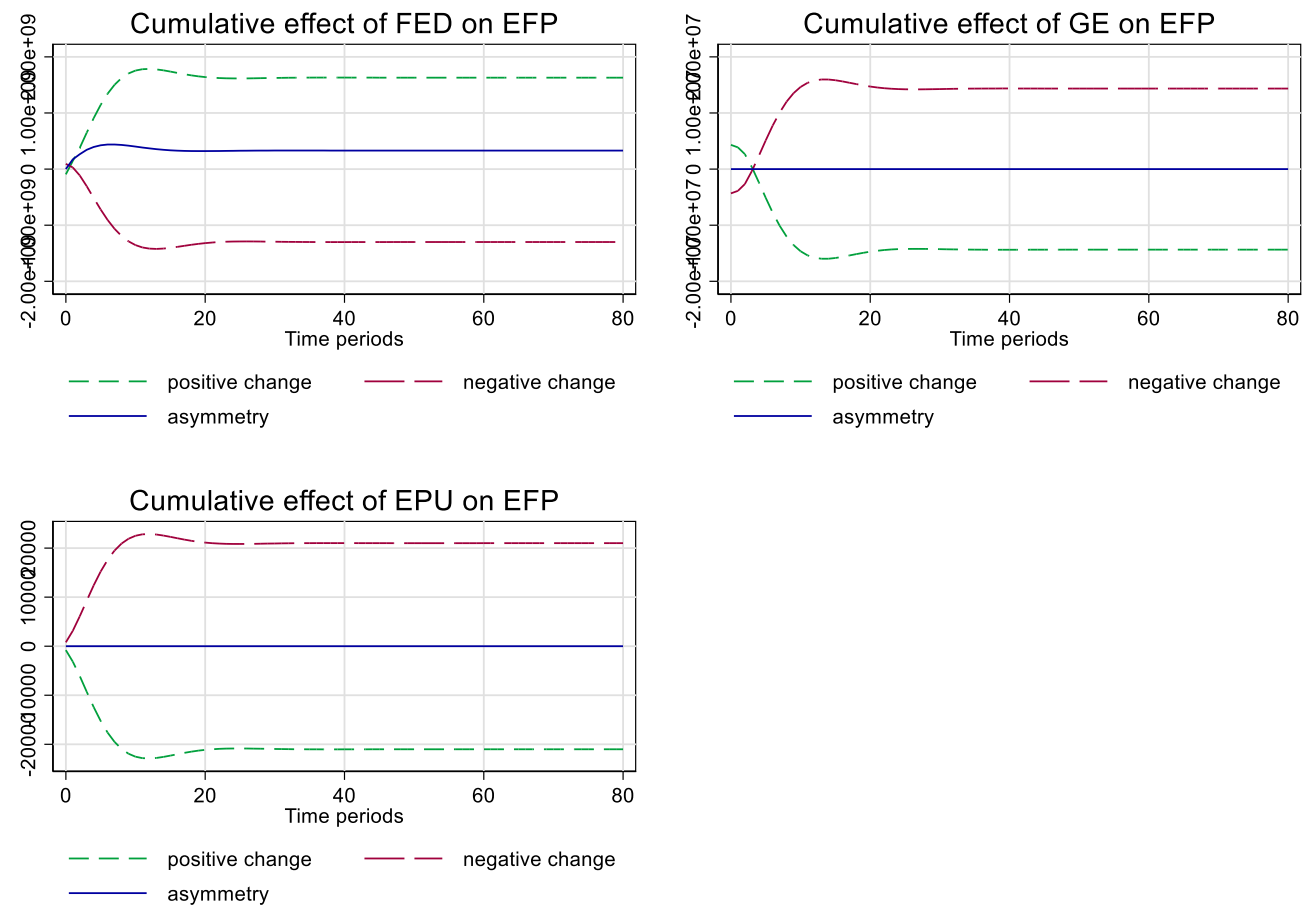

522

523 Fig. 2. Cumulative Effects of FED, GE, and EPU on EF for Australia 

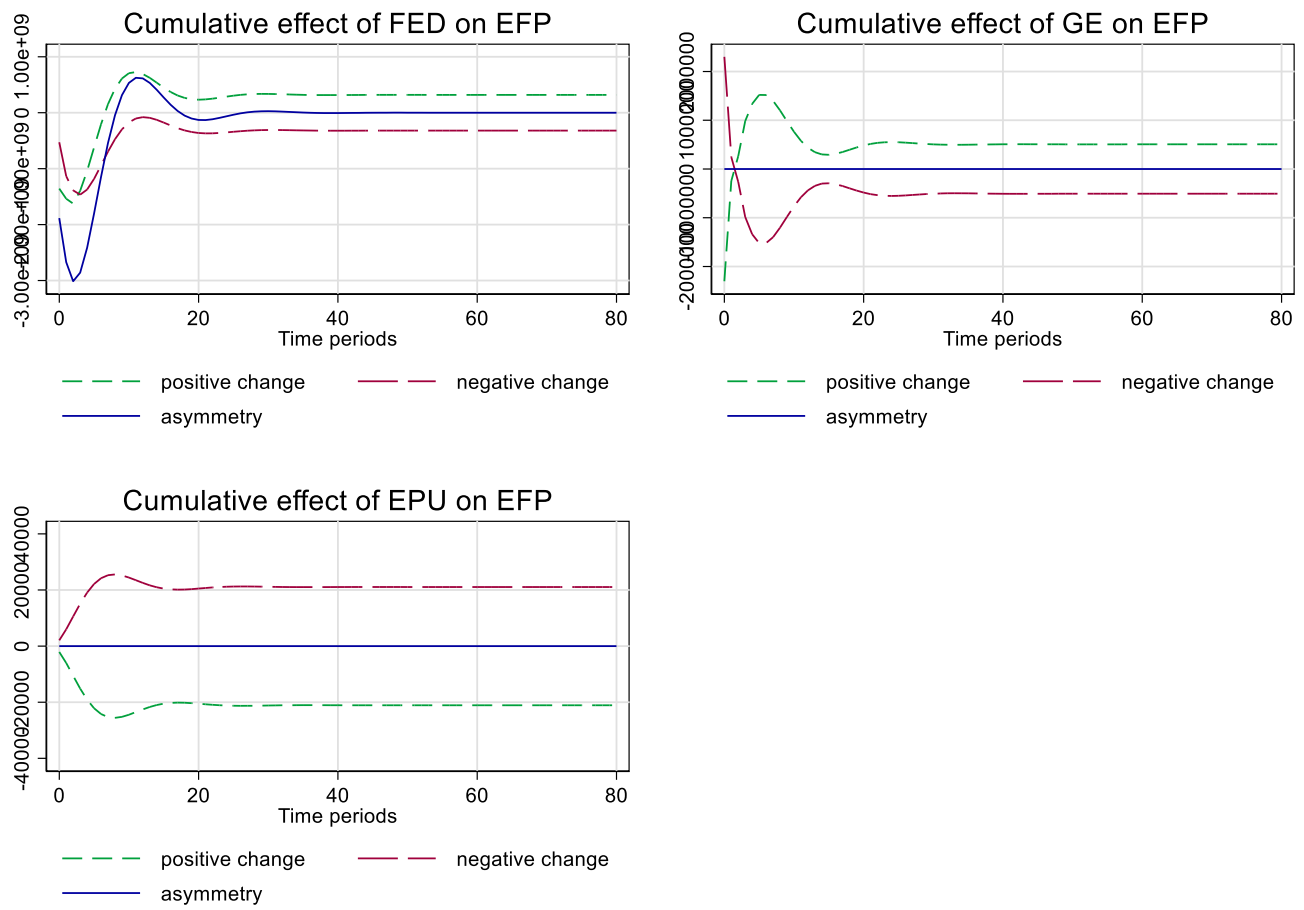

527

528 Fig. 3. Cumulative Effects of FED, GE, and EPU on EF for Canada 

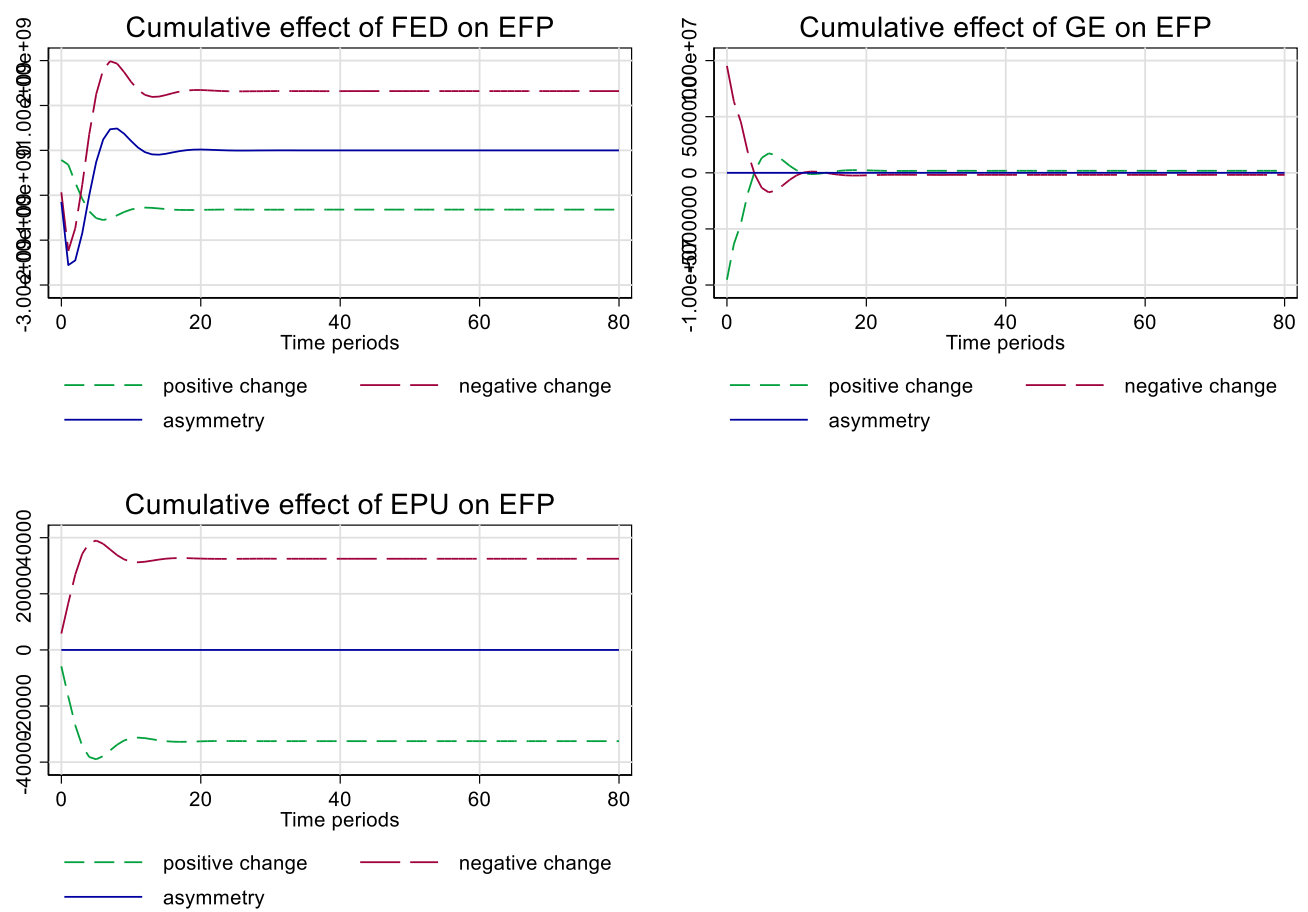

530

531 Fig. 4. Cumulative Effects of FED, GE, and EPU on EF for Germany 

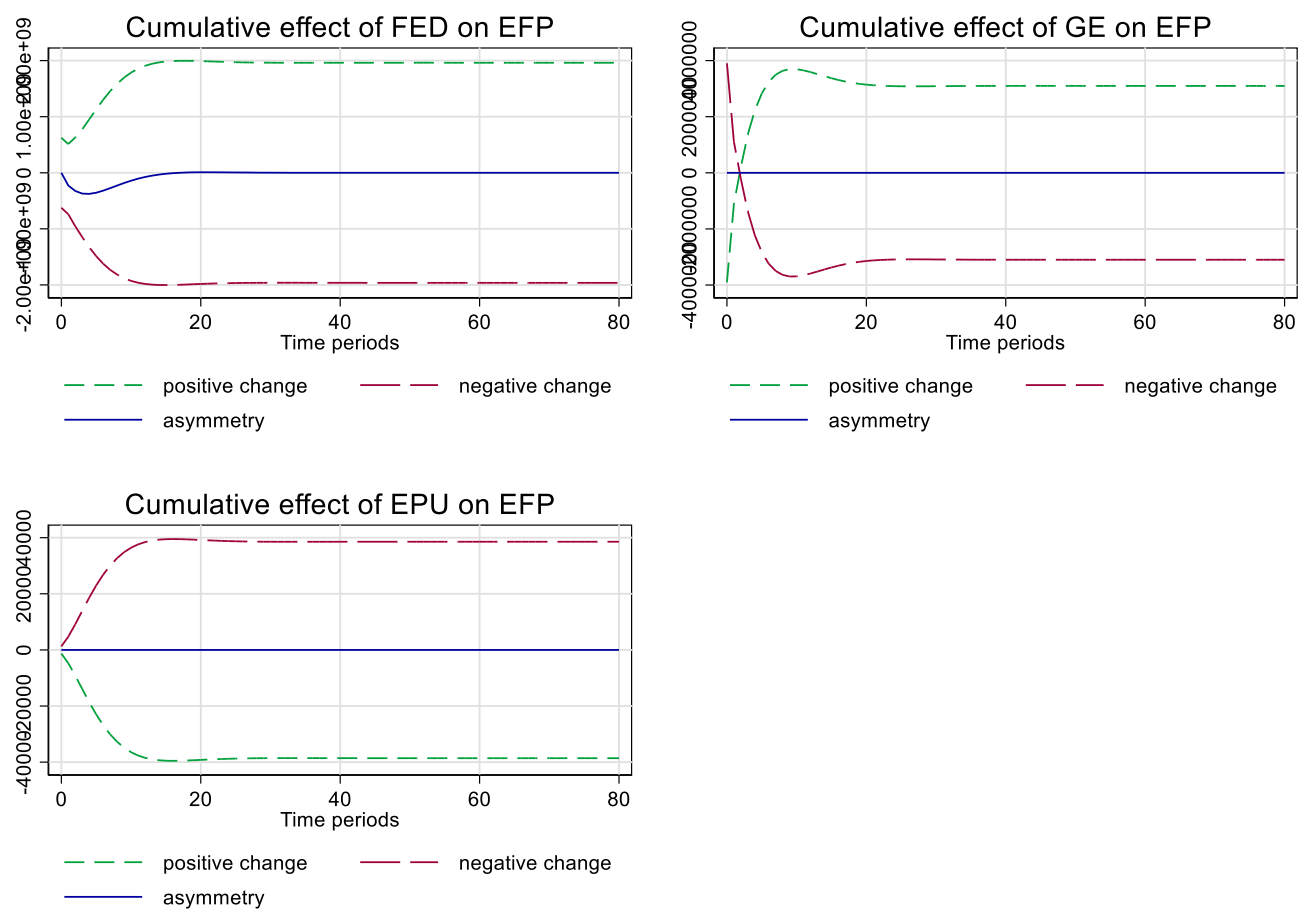

533

534 Fig. 5. Cumulative Effects of FED, GE, and EPU on EF for the United Kingdom 

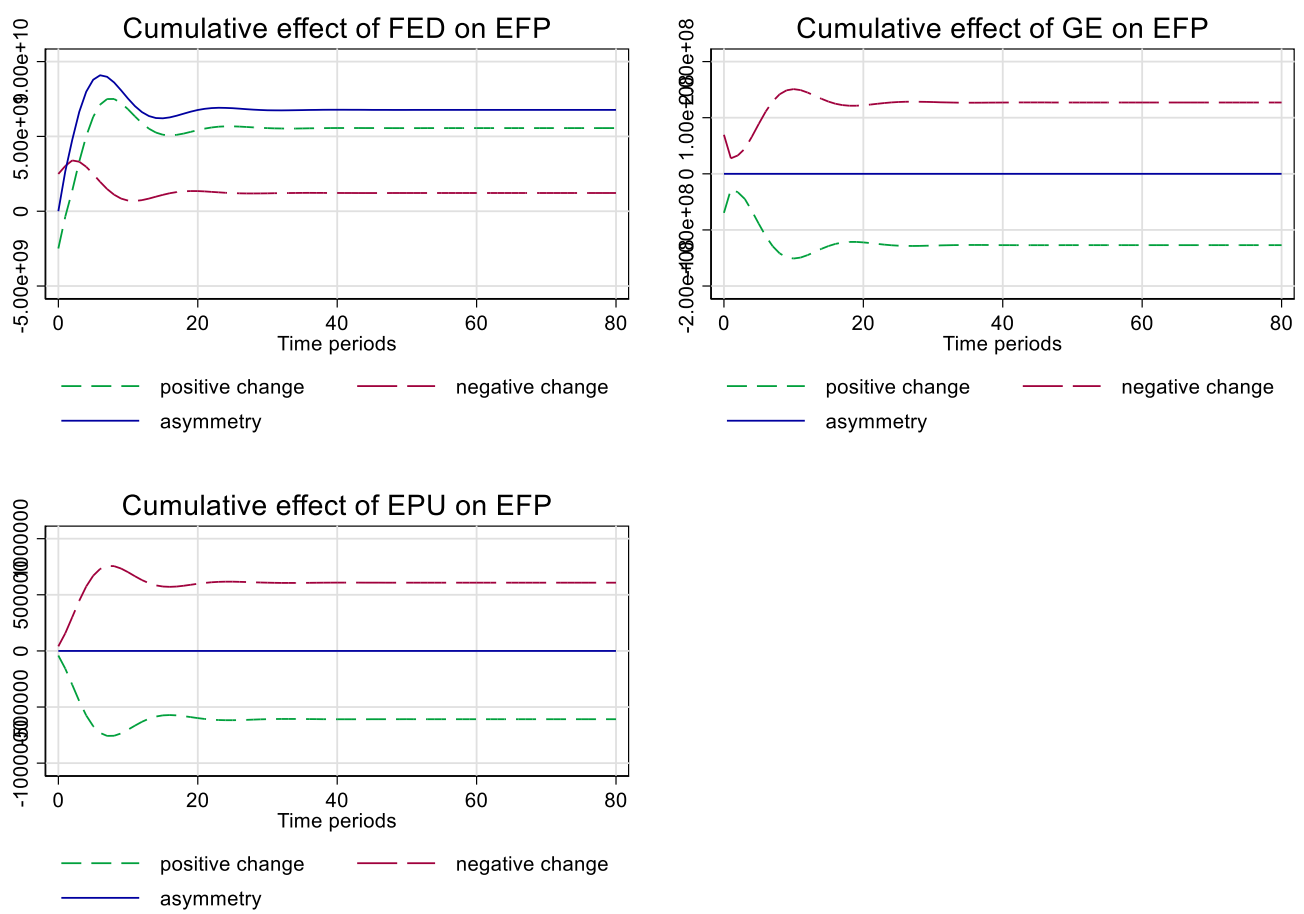

537 Fig. 6. Cumulative Effects of FED, GE and EPU on EF for the United States of America

\section{5. Conclusion and Policy Implications}

539 The main objective of this study is to empirically investigate the asymmetric or nonlinear

540 relationship between fiscal expenditure decentralization and ecological footprint as a proxy of

541 environmental sustainability both in the short-run and long-run in five selected OECD countries,

542 namely, Australia, Canada, Germany, United Kingdom and the United States of America. This

543 study also explains the empirical symmetric relationship between green energy, economic policy

544 uncertainty, and ecological footprint for these five OECD countries. The results show that fiscal

545 decentralization is asymmetrically correlated with an ecological footprint in the long run only in

546 the case of the USA and Australia, while in the short run, in both of these countries, these

547 variables are symmetrically associated. Contrary, in the United Kingdom, the asymmetric

548 relationship between fiscal expenditure decentralization and ecological footprint is neither found

549 in the long run nor in the short run. On the other hand, in the case of Canada and Germany, fiscal

550 decentralization is asymmetrically interlinked with an ecological footprint in the short run only,

551 while in the long run, there is a linear relationship between these two variables. Empirical 
552 evidence also shows that in the case of Australia and the USA, clean energy is a major 553 determinant of an ecological footprint both in the long run and short run.

554 On the contrary, in the case of Canada and the United Kingdom, clean or green energy is not the major determinant of an ecological footprint both in the long run and short run. On the other hand, in Germany, green energy is a major determinant of ecological footprint in the short run

557 but not in the long run. Another assumed determinant of ecological footprint is economic policy uncertainty. In Germany and the USA, economic policy uncertainty is a significant determinant of an ecological footprint both in the long and short run. On the contrary, economic policy uncertainty is not a significant variable of ecological footprint in Australia and Canada, both in 561 the long run and short run. While in the UK, it is a major determinant of ecological footprint in 562 the long run only. Specific policy implications are arising from this research. First, more financial resources should be allocated to control the environmental degradation along with more power delegation to countries institutions to design independent policies in very favor of environmental up-gradation and sustainability. Moreover, Central Governments should allocate more powers to local governments to further strengthen the fiscal expenditure decentralization and enhance the projects for clean energy to control environmental degradation. Along with this, increasing the fiscal expenditures ratio both in current and development spheres to improve environmental quality and thus sustainability is an effective tool to apply (Hao et al., 2020). Thus, is also 571 suggested for the selected OECD countries. Similarly, the "Free Riding" behavior of local 572 governments and the industrial sector, fiscal decentralization, should be curtailed by bounding 573 carbon shares in environmental degradation both in the short-run and long run. Setting special 574 autonomous bodies at local and provincial levels to monitor the institutional qualities to guard 575 environmental concerns can play an influential role in this regard. It is also suggested to

576 implement the carbon tax at the very root of provincial and local authority levels, which will play 577 an effective role like a two-way sword, which will not only surge government revenue thus will 578 prompt fiscal revenue decentralization and control environmental degradation, and upgrade 579 climate sustainability. Similarly, delegating more power to the provincial government to 580 manipulate the policies in favor of paradigm shift from extensive economic growth-oriented 581 models to low environmental degradation developmental models, especially low carbon 
economic growth models to achieve sustainability concerning environmental perspective, will be favorite.

The subsequent policy implication for these countries is to focus on a paradigm shift related to energy portfolio by accumulating the share of green energy in the total sphere of energy consumption. Similarly, proper planning for technological advancements and enhancements in the power sector to enhance carbon capture and storage is the need of the hour to subdue environmental degradation. Therefore it is indispensable to increase green investment to promote environmental quality. Another suggestion is to devise different credit or green credit mechanisms or systems to allow varying interest rates for industries depending on their parts into environmental degradation and carbon emission. The more polluting industries may offer credit at higher interest rates and vice versa, which will compel industries to innovate green or renewable energy production at their potential level. Likewise, industries with low carbon emissions should be given an incentive in the form of a low tax rate or tax exemptions. In parallel, importers should be given subsidies to import green energy products. These suggestions exhibit the collaboration of three crucial goals of Sustainable Development Goals (SDGs), which are to enhance economic growth (SDG no 8), with considering the problem of environmental degradation and to uplift the ecological quality (SDGs no 13) in addition to providing masses affordable green energy (SDG no 7).

Another vital recommendation to control economic policy uncertainty is implying very fair and transparent economic policies so that government authorities and officials can analyze the economic policy uncertainty transparently and diagnose economic illness and thus treat it properly and timely. At the global level, economic organizations such as World Trade Organization, United Nations Organizations, International Monetary Funds, and World Bank must campaign to shrink economic policy uncertainty both at the global and country-wise level.

Apart from these findings, there are certain limitations. Firstly, future studies may focus on finding the threshold level of fiscal decentralization to optimize economic growth with sustainable environmental goals, which is the very soul of SDGs. Secondly, World Uncertainty Index can be a relatively better proxy for monetary policy uncertainty which can be used in future studies for better policies suggestions. Thirdly, this research study assumes the impact of green energy on ecological footprint; however, energy segregation paves the way for future 
612 researchers to dissect the energy consumption role in enhancing ecological footprint with 613 particular reference to fiscal decentralization and economic policy uncertainty. Fourthly, this 614 research study assumes fiscal expenditure decentralization as a proxy to fiscal decentralization. 615 However, future studies can develop an index to aggregate the impact of both dimensions of 616 fiscal decentralization, namely, fiscal revenue decentralization and fiscal expenditure 617 decentralization.

Ethical Approval: Not Applicable

619 Consent to participate: I am free to contact any of the people involved in the research to seek 620 further clarification and information.

Consent to publish: Not applicable.

622 Authors' contributions: Samia Zahra: Conceptualization, Methodology, Formal Analysis, 623 Investigation, Writing-Review \& Editing Ramez Abubakr Badeeb: Methodology, Reviews and 624 Supevision

625 Funding: Not applicable.

626 Competing Interests: The authors declare no potential conflicts of interest concerning the 627 research, authorship, and publication of this article.

Data Availability: The datasets used and/or analyzed during the current study are available from the corresponding author on reasonable request.

\section{References}

Adams, S., \& Acheampong, A. O. (2019). Reducing carbon emissions: the role of renewable energy and democracy. Journal of cleaner production, 240, 118245.

Adams, S., Adedoyin, F., Olaniran, E., \& Bekun, F. V. (2020). Energy consumption, economic policy uncertainty and carbon emissions; causality evidence from resource rich economies. Economic Analysis and Policy, 68, 179-190.

Adedoyin, F. F., Ozturk, I., Agboola, M. O., Agboola, P. O., \& Bekun, F. V. (2021). The implications of renewable and non-renewable energy generating in Sub-Saharan Africa: The role of economic policy uncertainties. Energy Policy, 150, 112115.

Adedoyin, F. F., \& Zakari, A. (2020). Energy consumption, economic expansion, and CO2 emission in the UK: the role of economic policy uncertainty. Science of The Total Environment, 738, 140014. 
Ahmad, A., Zhao, Y., Shahbaz, M., Bano, S., Zhang, Z., Wang, S., \& Liu, Y. (2016). Carbon emissions, energy consumption and economic growth: An aggregate and disaggregate analysis of the Indian economy. Energy Policy, 96, 131-143.

Al-Mulali, U., Solarin, S. A., Sheau-Ting, L., \& Ozturk, I. (2016). Does moving towards renewable energy cause water and land inefficiency? An empirical investigation. Energy Policy, 93, 303-314.

Alola, A. A., Yalçiner, K., Alola, U. V., \& Saint Akadiri, S. (2019). The role of renewable energy, immigration and real income in environmental sustainability target. Evidence from Europe largest states. Science of The Total Environment, 674, 307-315.

Alvarado, R., Ponce, P., Criollo, A., Córdova, K., \& Khan, M. K. (2018). Environmental degradation and real per capita output: new evidence at the global level grouping countries by income levels. Journal of cleaner production, 189, 13-20.

Amin, A., \& Dogan, E. (2021). The role of economic policy uncertainty in the energy-environment nexus for China: Evidence from the novel dynamic simulations method. Journal of environmental management, 292, 112865.

Anser, M. K., Apergis, N., \& Syed, Q. R. (2021). Impact of economic policy uncertainty on CO 2 emissions: evidence from top ten carbon emitter countries. Environmental Science and Pollution Research, 1-10.

Atasoy, B. S. (2017). Testing the environmental Kuznets curve hypothesis across the US: Evidence from panel mean group estimators. Renewable and Sustainable Energy Reviews, 77, 731-747.

Atil, A., Lahiani, A., \& Nguyen, D. K. (2014). Asymmetric and nonlinear pass-through of crude oil prices to gasoline and natural gas prices. Energy Policy, 65, 567-573.

Azqueta-Gavaldón, A. (2017). Developing news-based economic policy uncertainty index with unsupervised machine learning. Economics letters, 158, 47-50.

Badeeb, R. A., \& Lean, H. H. (2018). Asymmetric impact of oil price on Islamic sectoral stocks. Energy Economics, 71, 128-139.

Badeeb, R. A., Lean, H. H., \& Shahbaz, M. (2020). Are too many natural resources to blame for the shape of the Environmental Kuznets Curve in resource-based economies? Resources Policy, 68, 101694.

Badeeb, R. A., Szulczyk, K. R., \& Lean, H. H. (2021). Asymmetries in the effect of oil rent shocks on economic growth: A sectoral analysis from the perspective of the oil curse. Resources Policy, 74, 102326.

Baker, S. R., Bloom, N., \& Davis, S. J. (2016). Measuring economic policy uncertainty. The quarterly journal of economics, 131(4), 1593-1636.

Baloch, M. A. (2018). Dynamic linkages between road transport energy consumption, economic growth, and environmental quality: evidence from Pakistan. Environmental Science and Pollution Research, 25(8), 7541-7552.

Baloch, M. A., Mahmood, N., \& Zhang, J. W. (2019). Effect of natural resources, renewable energy and economic development on $\mathrm{CO} 2$ emissions in BRICS countries. Science of The Total Environment, 678, 632-638.

Baloch, M. A., \& Suad, S. (2018). Modeling the impact of transport energy consumption on CO 2 emission in Pakistan: evidence from ARDL approach. Environmental Science and Pollution Research, 25(10), 9461-9473.

Baloch, M. A., Zhang, J., Iqbal, K., \& lqbal, Z. (2019). The effect of financial development on ecological footprint in BRI countries: evidence from panel data estimation. Environmental Science and Pollution Research, 26(6), 6199-6208.

Batterbury, S. P., \& Fernando, J. L. (2006). Rescaling governance and the impacts of political and environmental decentralization: an introduction. World Development, 34(11), 1851-1863. 
Baz, K., Xu, D., Ali, H., Ali, I., Khan, I., Khan, M. M., \& Cheng, J. (2020). Asymmetric impact of energy consumption and economic growth on ecological footprint: using asymmetric and nonlinear approach. Science of The Total Environment, 718, 137364.

Bekhet, H. A., Matar, A., \& Yasmin, T. (2017). CO2 emissions, energy consumption, economic growth, and financial development in GCC countries: Dynamic simultaneous equation models. Renewable and Sustainable Energy Reviews, 70, 117-132.

Bello, M. O., Solarin, S. A., \& Yen, Y. Y. (2018). The impact of electricity consumption on CO2 emission, carbon footprint, water footprint and ecological footprint: the role of hydropower in an emerging economy. Journal of environmental management, 219, 218-230.

Breusch, T. S. (1978). Testing for autocorrelation in dynamic linear models. Australian Economic Papers, 17(31), 334-355.

Caviglia-Harris, J. L., Chambers, D., \& Kahn, J. R. (2009). Taking the "U" out of Kuznets: A comprehensive analysis of the EKC and environmental degradation. Ecological Economics, 68(4), 1149-1159.

Charfeddine, L. (2017). The impact of energy consumption and economic development on ecological footprint and $\mathrm{CO} 2$ emissions: evidence from a Markov switching equilibrium correction model. Energy Economics, 65, 355-374.

Charfeddine, L., \& Kahia, M. (2019). Impact of renewable energy consumption and financial development on $\mathrm{CO} 2$ emissions and economic growth in the MENA region: a panel vector autoregressive (PVAR) analysis. Renewable Energy, 139, 198-213.

Charfeddine, L., \& Mrabet, Z. (2017). The impact of economic development and social-political factors on ecological footprint: A panel data analysis for 15 MENA countries. Renewable and Sustainable Energy Reviews, 76, 138-154.

Chen, B., Chen, G., Yang, Z., \& Jiang, M. (2007). Ecological footprint accounting for energy and resource in China. Energy Policy, 35(3), 1599-1609.

Chen, C.-Z., \& Lin, Z.-S. (2008). Multiple timescale analysis and factor analysis of energy ecological footprint growth in China 1953-2006. Energy Policy, 36(5), 1666-1678.

Chen, H., Hao, Y., Li, J., \& Song, X. (2018). The impact of environmental regulation, shadow economy, and corruption on environmental quality: Theory and empirical evidence from China. Journal of cleaner production, 195, 200-214.

Chen, S., Saleem, N., \& Bari, M. W. (2019). Financial development and its moderating role in environmental Kuznets curve: evidence from Pakistan. Environmental Science and Pollution Research, 26(19), 19305-19319.

Chen, X., \& Chang, C.-P. (2020). Fiscal decentralization, environmental regulation, and pollution: a spatial investigation. Environmental Science and Pollution Research, 27, 31946-31968.

Cheng, M., Chung, L., Tam, C.-S., Yuen, R., Chan, S., \& Yu, I.-W. (2012). Tracking the Hong Kong Economy. Occasional Paper, 3, 2012.

Cheng, S., Fan, W., Chen, J., Meng, F., Liu, G., Song, M., \& Yang, Z. (2020). The impact of fiscal decentralization on CO2 emissions in China. Energy, 192, 116685.

Cheng, Y., Awan, U., Ahmad, S., \& Tan, Z. (2021). How do technological innovation and fiscal decentralization affect the environment? A story of the fourth industrial revolution and sustainable growth. Technological Forecasting and Social Change, 162, 120398.

Chu, L. K., \& Le, N. T. M. (2021). Environmental quality and the role of economic policy uncertainty, economic complexity, renewable energy, and energy intensity: the case of G7 countries. Environmental Science and Pollution Research, 1-17.

Clemente, J., Montañés, A., \& Reyes, M. (1998). Testing for a unit root in variables with a double change in the mean. Economics letters, 59(2), 175-182. 
de Souza, E. S., de Souza Freire, F., \& Pires, J. (2018). Determinants of CO 2 emissions in the MERCOSUR: the role of economic growth, and renewable and non-renewable energy. Environmental Science and Pollution Research, 25(21), 20769-20781.

Destek, M. A., \& Sarkodie, S. A. (2019). Investigation of environmental Kuznets curve for ecological footprint: the role of energy and financial development. Science of The Total Environment, 650, 2483-2489.

Destek, M. A., \& Sinha, A. (2020). Renewable, non-renewable energy consumption, economic growth, trade openness and ecological footprint: Evidence from organisation for economic Co-operation and development countries. Journal of cleaner production, 242, 118537.

Destek, M. A., Ulucak, R., \& Dogan, E. (2018). Analyzing the environmental Kuznets curve for the EU countries: the role of ecological footprint. Environmental Science and Pollution Research, 25(29), 29387-29396.

Dogan, E., \& Ozturk, I. (2017). The influence of renewable and non-renewable energy consumption and real income on $\mathrm{CO} 2$ emissions in the USA: evidence from structural break tests. Environmental Science and Pollution Research, 24(11), 10846-10854.

Dogan, E., \& Seker, F. (2016). The influence of real output, renewable and non-renewable energy, trade and financial development on carbon emissions in the top renewable energy countries. Renewable and Sustainable Energy Reviews, 60, 1074-1085.

Dogan, E., Taspinar, N., \& Gokmenoglu, K. K. (2019). Determinants of ecological footprint in MINT countries. Energy \& Environment, 30(6), 1065-1086.

Du, J., \& Sun, Y. (2021). The nonlinear impact of fiscal decentralization on carbon emissions: from the perspective of biased technological progress. Environmental Science and Pollution Research, 28(23), 29890-29899.

Esso, L. J., \& Keho, Y. (2016). Energy consumption, economic growth and carbon emissions: Cointegration and causality evidence from selected African countries. Energy, 114, 492-497.

Esty, D. C. (1996). Revitalizing environmental federalism. Michigan Law Review, 95(3), 570-653.

Faisal, F., Tursoy, T., \& Berk, N. (2018). Linear and non-linear impact of Internet usage and financial deepening on electricity consumption for Turkey: empirical evidence from asymmetric causality. Environmental Science and Pollution Research, 25(12), 11536-11555.

Farzanegan, M. R., \& Mennel, T. (2012). Fiscal decentralization and pollution: Institutions matter. Retrieved from

Fell, H., \& Kaffine, D. T. (2014). Can decentralized planning really achieve first-best in the presence of environmental spillovers? Journal of Environmental Economics and Management, 68(1), 46-53.

Godfrey, L. G. (1978). Testing for higher order serial correlation in regression equations when the regressors include lagged dependent variables. Econometrica: Journal of the Econometric Society, 1303-1310.

Hao, Y., Chen, Y.-F., Liao, H., \& Wei, Y.-M. (2020). China's fiscal decentralization and environmental quality: theory and an empirical study. Environment and Development Economics, 25(2), 159181.

He, C., Pan, F., \& Yan, Y. (2012). Is economic transition harmful to China's urban environment? Evidence from industrial air pollution in Chinese cities. Urban Studies, 49(8), 1767-1790.

$\mathrm{He}, \mathrm{Q}$. (2015). Fiscal decentralization and environmental pollution: Evidence from Chinese panel data. China Economic Review, 36, 86-100.

Ibrahim, M. H. (2015). Oil and food prices in Malaysia: a nonlinear ARDL analysis. Agricultural and Food Economics, 3(1), 1-14.

Jafri, M. A. H., Liu, H., Majeed, M. T., Ahmad, W., Ullah, S., \& Xue, R. (2021). Physical infrastructure, energy consumption, economic growth, and environmental pollution in Pakistan: an asymmetry analysis. Environmental Science and Pollution Research, 28(13), 16129-16139. 
Ji, X., Umar, M., Ali, S., Ali, W., Tang, K., \& Khan, Z. (2021). Does fiscal decentralization and eco-innovation promote sustainable environment? A case study of selected fiscally decentralized countries. Sustainable Development, 29(1), 79-88.

Jiang, Y., Zhou, Z., \& Liu, C. (2019). Does economic policy uncertainty matter for carbon emission? Evidence from US sector level data. Environmental Science and Pollution Research, 26(24), 24380-24394.

Khan, H., Khan, I., \& Binh, T. T. (2020). The heterogeneity of renewable energy consumption, carbon emission and financial development in the globe: a panel quantile regression approach. Energy Reports, 6, 859-867.

Kisswani, K. M., Zaitouni, M., \& Moufakkir, O. (2020). An examination of the asymmetric effect of oil prices on tourism receipts. Current Issues in Tourism, 23(4), 500-522.

Kuai, P., Yang, S., Tao, A., \& Khan, Z. D. (2019). Environmental effects of Chinese-style fiscal decentralization and the sustainability implications. Journal of cleaner production, 239, 118089.

Kunce, M., \& Shogren, J. F. (2008). Efficient decentralized fiscal and environmental policy: A dual purpose Henry George tax. Ecological Economics, 65(3), 569-573.

Li, X., Younas, M. Z., Andlib, Z., Ullah, S., Sohail, S., \& Hafeez, M. (2021). Examining the asymmetric effects of Pakistan's fiscal decentralization on economic growth and environmental quality. Environmental Science and Pollution Research, 28(5), 5666-5681.

Liu, J., Chen, X., \& Wei, R. (2017). Socioeconomic drivers of environmental pollution in China: a spatial econometric analysis. Discrete Dynamics in Nature and Society, 2017.

Liu, L., Ding, D., \& He, J. (2019). Fiscal decentralization, economic growth, and haze pollution decoupling effects: a simple model and evidence from China. Computational Economics, 54(4), 1423-1441.

Liu, L., \& Li, L. (2019). Effects of fiscal decentralisation on the environment: new evidence from China. Environmental Science and Pollution Research, 26(36), 36878-36886.

Ljungwall, C., \& Linde-Rahr, M. (2005). Environmental policy and the location of foreign direct investment in China. Governance Working Papers, 22020.

Majeed, M. T., \& Luni, T. (2019). Renewable energy, water, and environmental degradation: A global panel data approach. Pakistan Journal of Commerce and Social Sciences (PJCSS), 13(3), 749-778.

Majeed, M. T., \& Tauqir, A. (2020). Effects of urbanization, industrialization, economic growth, energy consumption, financial development on carbon emissions: an extended STIRPAT model for heterogeneous income groups. Pakistan Journal of Commerce and Social Sciences (PJCSS), 14(3), 652-681.

Majeed, M. T., Tauqir, A., Mazhar, M., \& Samreen, I. (2021). Asymmetric effects of energy consumption and economic growth on ecological footprint: new evidence from Pakistan. Environmental Science and Pollution Research, 1-17.

Mrabet, Z., \& Alsamara, M. (2017). Testing the Kuznets Curve hypothesis for Qatar: A comparison between carbon dioxide and ecological footprint. Renewable and Sustainable Energy Reviews, 70, 1366-1375.

Munir, K., \& Riaz, N. (2020). Asymmetric impact of energy consumption on environmental degradation: evidence from Australia, China, and USA. Environmental Science and Pollution Research, 1-11.

Nathaniel, S., Anyanwu, O., \& Shah, M. (2020). Renewable energy, urbanization, and ecological footprint in the Middle East and North Africa region. Environmental Science and Pollution Research, 1-13.

Ozcan, B., Apergis, N., \& Shahbaz, M. (2018). A revisit of the environmental Kuznets curve hypothesis for Turkey: new evidence from bootstrap rolling window causality. Environmental Science and Pollution Research, 25(32), 32381-32394.

Ozcan, B., Tzeremes, P. G., \& Tzeremes, N. G. (2020). Energy consumption, economic growth and environmental degradation in OECD countries. Economic Modelling, 84, 203-213. 
Ozturk, I., \& Acaravci, A. (2013). The long-run and causal analysis of energy, growth, openness and financial development on carbon emissions in Turkey. Energy Economics, 36, 262-267.

Ozturk, I., Al-Mulali, U., \& Saboori, B. (2016). Investigating the environmental Kuznets curve hypothesis: the role of tourism and ecological footprint. Environmental Science and Pollution Research, 23(2), 1916-1928.

Öztürk, I.., Draz, M. U., Ahmad, F., Su, L., \& Rauf, A. (2020). Looking for asymmetries and nonlinearities: The nexus between renewable energy and environmental degradation in the Northwestern provinces of China.

Pao, H.-T., \& Tsai, C.-M. (2010). CO2 emissions, energy consumption and economic growth in BRIC countries. Energy Policy, 38(12), 7850-7860.

Pao, H.-T., \& Tsai, C.-M. (2011). Multivariate Granger causality between CO2 emissions, energy consumption, FDI (foreign direct investment) and GDP (gross domestic product): evidence from a panel of BRIC (Brazil, Russian Federation, India, and China) countries. Energy, 36(1), 685-693.

Pata, U. K. (2021). Linking renewable energy, globalization, agriculture, $\mathrm{CO} 2$ emissions and ecological footprint in BRIC countries: A sustainability perspective. Renewable Energy, 173, 197-208.

Pirgaip, B., \& Dinçergök, B. (2020). Economic policy uncertainty, energy consumption and carbon emissions in $\mathrm{G} 7$ countries: evidence from a panel Granger causality analysis. Environmental Science and Pollution Research, 27, 30050-30066.

Que, W., Zhang, Y., Liu, S., \& Yang, C. (2018). The spatial effect of fiscal decentralization and factor market segmentation on environmental pollution. Journal of cleaner production, 184, 402-413.

Ramsey, J. B. (1969). Tests for specification errors in classical linear least-squares regression analysis. Journal of the Royal Statistical Society: Series B (Methodological), 31(2), 350-371.

Rasoulinezhad, E., \& Saboori, B. (2018). Panel estimation for renewable and non-renewable energy consumption, economic growth, $\mathrm{CO} 2$ emissions, the composite trade intensity, and financial openness of the commonwealth of independent states. Environmental Science and Pollution Research, 25(18), 17354-17370.

Riti, J. S., \& Shu, Y. (2016). Renewable energy, energy efficiency, and eco-friendly environment (RE 5) in Nigeria. Energy, Sustainability and Society, 6(1), 1-16.

Saboori, B., \& Sulaiman, J. (2013). Environmental degradation, economic growth and energy consumption: Evidence of the environmental Kuznets curve in Malaysia. Energy Policy, 60, 892905.

Sarkodie, S. A., Adams, S., Owusu, P. A., Leirvik, T., \& Ozturk, I. (2020). Mitigating degradation and emissions in China: the role of environmental sustainability, human capital and renewable energy. Science of The Total Environment, 719, 137530.

Shahbaz, M., Lean, H. H., \& Shabbir, M. S. (2012). Environmental Kuznets curve hypothesis in Pakistan: cointegration and Granger causality. Renewable and Sustainable Energy Reviews, 16(5), 29472953.

Shan, S., Ahmad, M., Tan, Z., Adebayo, T. S., Li, R. Y. M., \& Kirikkaleli, D. (2021). The role of energy prices and non-linear fiscal decentralization in limiting carbon emissions: Tracking environmental sustainability. Energy, 234, 121243.

Shi, Y., Chang, C.-P., Jang, C.-L., \& Hao, Y. (2018). Does economic performance affect officials' turnover? Evidence from municipal government leaders in China. Quality \& Quantity, 52(4), 1873-1891.

Shin, Y., Yu, B., \& Greenwood-Nimmo, M. (2014). Modelling asymmetric cointegration and dynamic multipliers in a nonlinear ARDL framework. In Festschrift in honor of Peter Schmidt (pp. 281314): Springer.

Sigman, H. (2007). Decentralization and environmental quality: an international analysis of water pollution. In: National Bureau of Economic Research Cambridge, Mass., USA. 
Sigman, H. (2014). Decentralization and environmental quality: an international analysis of water pollution levels and variation. Land Economics, 90(1), 114-130.

Sohail, M. T., Ullah, S., Majeed, M. T., \& Usman, A. (2021). Pakistan management of green transportation and environmental pollution: a nonlinear ARDL analysis. Environmental Science and Pollution Research, 1-10.

Solarin, S. A., Al-Mulali, U., Musah, I., \& Ozturk, I. (2017). Investigating the pollution haven hypothesis in Ghana: an empirical investigation. Energy, 124, 706-719.

Su, C.-W., Umar, M., \& Khan, Z. (2021). Does fiscal decentralization and eco-innovation promote renewable energy consumption? Analyzing the role of political risk. Science of The Total Environment, 751, 142220.

Swain, R. B., \& Karimu, A. (2020). Renewable electricity and sustainable development goals in the EU. World Development, 125, 104693.

Syed, Q. R., \& Bouri, E. (2021). Impact of economic policy uncertainty on $\mathrm{CO} 2$ emissions in the US: Evidence from bootstrap ARDL approach. Journal of Public Affairs, e2595.

Taguchi, H., \& Murofushi, H. (2010). Evidence on the interjurisdictional competition for polluted industries within China. Environment and Development Economics, 15(3), 363-378.

Türsoy, T., \& Faisal, F. (2018). Does financial depth impact economic growth in North Cyprus? Financial Innovation, 4(1), 1-13.

Ulucak, R., \& Khan, S. U. D. (2020). Relationship between energy intensity and CO2 emissions: Does economic policy matter? Sustainable Development, 28(5), 1457-1464.

Usman, O., Akadiri, S. S., \& Adeshola, I. (2020). Role of renewable energy and globalization on ecological footprint in the USA: implications for environmental sustainability. Environmental Science and Pollution Research, 27, 30681-30693.

Vural-Yavaş, Ç. (2021). Economic policy uncertainty, stakeholder engagement, and environmental, social, and governance practices: The moderating effect of competition. Corporate Social Responsibility and Environmental Management, 28(1), 82-102.

Wang, K.-H., Liu, L., Adebayo, T. S., Lobon, O.-R., \& Claudia, M. N. (2021). Fiscal decentralization, political stability and resources curse hypothesis: A case of fiscal decentralized economies. Resources Policy, 72, 102071.

Wang, L., \& Lei, P. (2016). Fiscal decentralization and high-polluting industry development: city-level evidence from Chinese panel data. International Journal of Smart Home, 10(9), 297-308.

Wang, Q., Xiao, K., \& Lu, Z. (2020). Does economic policy uncertainty affect CO2 emissions? Empirical evidence from the United States. Sustainability, 12(21), 9108.

Wang, S., Zhou, D., Zhou, P., \& Wang, Q. (2011). CO2 emissions, energy consumption and economic growth in China: A panel data analysis. Energy Policy, 39(9), 4870-4875.

Wang, Z., Bui, Q., \& Zhang, B. (2020). The relationship between biomass energy consumption and human development: Empirical evidence from BRICS countries. Energy, 194, 116906.

Wang, Z., Zhang, B., \& Wang, B. (2018). Renewable energy consumption, economic growth and human development index in Pakistan: evidence form simultaneous equation model. Journal of cleaner production, 184, 1081-1090.

Yang, Y., Tang, D., \& Zhang, P. (2020). Effects of fiscal decentralization on carbon emissions in China. International Journal of Energy Sector Management.

You, D., Zhang, Y., \& Yuan, B. (2019). Environmental regulation and firm eco-innovation: Evidence of moderating effects of fiscal decentralization and political competition from listed Chinese industrial companies. Journal of cleaner production, 207, 1072-1083.

Yu, J., Shi, X., Guo, D., \& Yang, L. (2021). Economic policy uncertainty (EPU) and firm carbon emissions: Evidence using a China provincial EPU index. Energy Economics, 94, 105071. 
Zaidi, S. A. H., Hou, F., \& Mirza, F. M. (2018). The role of renewable and non-renewable energy consumption in $\mathrm{CO} 2$ emissions: a disaggregate analysis of Pakistan. Environmental Science and Pollution Research, 25(31), 31616-31629.

Zakari, A., Adedoyin, F. F., \& Bekun, F. V. (2021). The effect of energy consumption on the environment in the OECD countries: economic policy uncertainty perspectives. Environmental Science and Pollution Research, 1-11.

Zandi, G., \& Haseeb, M. (2019). The importance of green energy consumption and agriculture in reducing environmental degradation: Evidence from sub-Saharan African countries. International Journal of Financial Research, 10(5), 215-227.

Zhang, B., Wang, B., \& Wang, Z. (2017). Role of renewable energy and non-renewable energy consumption on EKC: evidence from Pakistan. Journal of cleaner production, 156, 855-864.

Zhang, B., Wang, Z., \& Wang, B. (2018). Energy production, economic growth and CO 2 emission: evidence from Pakistan. Natural Hazards, 90(1), 27-50.

Zhang, K., Zhang, Z.-Y., \& Liang, Q.-M. (2017). An empirical analysis of the green paradox in China: From the perspective of fiscal decentralization. Energy Policy, 103, 203-211.

Zhao, J., Li, G., Su, Y., \& Liu, J.-g. (2013). Regional differences and convergence analysis of energy efficiency in China: on stochastic frontier analysis and panel unit root. Chin J Manag Sci, 21, 175184. 